University of New Hampshire

University of New Hampshire Scholars' Repository

Earth Systems Research Center

Institute for the Study of Earth, Oceans, and

Space (EOS)

2018

\title{
Carbon fluxes and interannual drivers in a temperate forest ecosystem assessed through comparison of top-down and bottom-up approaches
}

\author{
Andrew P. Ouimette \\ University of New Hampshire \\ Scott V. Ollinger \\ University of New Hampshire \\ Andrew D. Richardson \\ Harvard University \\ Ravid Y Hollinger \\ ol 0 w this and additional works at: https:/scholars.unh.edu/ersc \\ Part of the Biogeochemistry Commons, Forest Biology Commons, and the Terrestrial and Aquatic \\ Treyor F.Keenan \\ LawretyceBerkeley National Lab
}

\section{Comments}

This is an Accepted Manuscript of an article published by Elsevier in Agricultural and Forest Meteorology in 2018, See next page for additional authors

available online: https://www.sciencedirect.com/science/article/pii/S016819231830100X. This manuscript version is

made available under the CC-BY-NC-ND 4.0 license http://creativecommons.org/licenses/by-nc-nd/4.0/

\section{Recommended Citation}

Ouimette, AP, Ollinger SV, Richardson AD, Hollinger DY, Keenan TF, Lepine LC, and Vadeboncoeur MA. 2018. Carbon fluxes and interannual drivers in a temperate forest ecosystem assessed through comparison of top-down and bottom-up approaches. Agricultural and Forest Meteorology 256-257: $420-430$.

This Article is brought to you for free and open access by the Institute for the Study of Earth, Oceans, and Space (EOS) at University of New Hampshire Scholars' Repository. It has been accepted for inclusion in Earth Systems Research Center by an authorized administrator of University of New Hampshire Scholars' Repository. For more information, please contact Scholarly.Communication@unh.edu. 
Authors

Andrew P. Ouimette, Scott V. Ollinger, Andrew D. Richardson, David Y. Hollinger, Trevor F. Keenan, Lucie C. Lepine, and Matthew A. Vadeboncoeur 


\section{Carbon fluxes and interannual drivers in a temperate forest ecosystem assessed through comparison of top-down and bottom-up approaches}

Andrew P. Ouimette ${ }^{\mathrm{a} *}$, Scott V. Ollinger ${ }^{\mathrm{a}}$, Andrew D. Richardson ${ }^{\mathrm{b}}$, David Y. Hollinger ${ }^{\mathrm{c}}$, Trevor F. Keenan ${ }^{\mathrm{d}}$, Lucie C. Lepine ${ }^{\mathrm{a}}$, Matthew A. Vadeboncoeur ${ }^{\mathrm{a}}$

${ }^{a}$ University of New Hampshire, Earth Systems Research Center, Durham, NH 03824

${ }^{\mathrm{b}}$ Harvard University, Department of Organismic and Evolutionary Biology, Cambridge MA 02138

${ }^{c}$ USDA Forest Service, Northern Research Station, 271 Mast Rd, Durham, NH 03824

${ }^{\text {d} E a r t h ~ S c i e n c e s ~ D i v i s i o n, ~ L a w r e n c e ~ B e r k e l e y ~ N a t i o n a l ~ L a b, ~ B e r k e l e y, ~ C A ~ 94709, ~ U S A ~}$

This accepted manuscript version is made available by the authors in accordance with Elsevier's self-archiving policy. The version of record is available from the publisher at: https://doi.org/10.1016/j.agrformet.2018.03.017

This document should be cited as:

Ouimette, AP, Ollinger SV, Richardson AD, Hollinger DY, Keenan TF, Lepine LC, and Vadeboncoeur MA. 2018. Carbon fluxes and interannual drivers in a temperate forest ecosystem assessed through comparison of top-down and bottom-up approaches. Agricultural and Forest Meteorology 256-257: 420-430. 


\section{Abstract}

2 Despite decades of research, gaining a comprehensive understanding of carbon (C)

3 cycling in forests remains a considerable challenge. Uncertainties stem from persistent

4 methodological limitations and the difficulty of resolving top-down estimates of

5 ecosystem C exchange with bottom-up measurements of individual pools and fluxes. To

6 address this, we derived estimates and associated uncertainties of ecosystem C fluxes for

7 a 100-125 year old mixed temperate forest stand at the Bartlett Experimental Forest, New

8 Hampshire, USA, using three different approaches: (1) tower-based eddy covariance, (2)

9 a biometric approach involving $\mathrm{C}$ flux measurements of individual ecosystem

10 subcomponents, and (3) an inventory approach involving changes in major $\mathrm{C}$ stocks over

11 time. Our analysis made use of 13 years of data, collected over the period from 2004 to

122016.

13 Estimates of mean annual net ecosystem production (NEP) ranged from 120-133

$14 \mathrm{~g} \mathrm{C} \mathrm{m}^{-2}$, demonstrating strong agreement among methods and suggesting that this aging

15 forest acts as a moderate $\mathrm{C}$ sink. The use of multiple approaches to measure $\mathrm{C}$ fluxes and

16 their uncertainties helped place constraints on difficult-to-measure processes such as

17 aboveground contributions to ecosystem respiration and belowground allocation to

18 mycorrhizal fungal biomass (which was estimated at $20 \%$ of net primary production).

19 Analysis of interannual variability in $\mathrm{C}$ fluxes revealed a decoupling between

20 annual wood growth and either current year or lagged NEP or GPP, suggesting that

21 source limitation (C supply) is likely not controlling rates of wood production, at least on

22 an interannual scale. Results also demonstrated a strong association between the

23 maximum rate of $\mathrm{C}$ uptake during the growing season (Amax) and the length of the 
24 vernal window, defined as the period of time between soil thaw and the onset of

25 photosynthesis. This suggests an important, but poorly understood, influence of winter

26 and spring climate on mid-summer canopy physiology. Efforts to resolve the

27 mechanisms responsible should be prioritized in light of ongoing and predicted changes

28 in climate for the northeastern U.S. region, particularly during the winter and winter-

29 spring transition period.

30

$31 *$ Corresponding author; $\underline{\text { Andrew.Ouimette@unh.edu }}$ 


\section{1. Introduction}

33 Forests represent the dominant land cover type in the northeastern United States (Foster

34 and Aber. 2004) and are widely regarded as carbon sinks given their state of recovery

35 from widespread agriculture in the $19^{\text {th }}$ century (Caspersen et al., 2000; Goodale et al.,

36 2002). However, the ability of these aging secondary forests to continue to act as net

37 carbon sinks as they transition to late-successional stands is unclear. Although a

38 commonly accepted view is that old-growth forests are carbon neutral (Odum, 1969),

39 more recent reviews indicate that late successional forests can often act as net carbon

40 sinks (Luyssaert et al., 2008). Additional data on the net carbon flux of eastern North

41 American forests should improve our understanding of the ability of these forests to

42 continue to act as net carbon sinks.

43 Approaches to estimating net $\mathrm{C}$ exchange in forests include eddy covariance flux

44 towers, biometric estimates of growth and respiration, and changes in important $\mathrm{C}$ stocks

45 over time. Each of these has inherent strengths and limitations. Eddy flux towers

46 provide direct measurements of net $\mathrm{CO}_{2}$ exchange at high temporal resolution, but can

47 suffer from unquantified advective losses (e.g. Aubinet et al., 2012; Novick et al., 2014;

48 van Gorsel et al., 2009; Vickers et al., 2012), data gaps during calm periods, and non- $\mathrm{CO}_{2}$

49 C fluxes. Eddy flux measurements also lack information on how $\mathrm{C}$ is allocated to various

50 ecosystem components (e.g. foliage, wood, fine roots, mycorrhizal fungi), that possess a

51 range of functions and $\mathrm{C}$ residence times and that are required to more fully test

52 ecosystem models.

53 Biometric approaches that quantify the difference between net primary production

54 (NPP) and heterotrophic respiration $\left(\mathrm{R}_{\mathrm{h}}\right)$, can provide independent estimates of net 
55 ecosystem $\mathrm{C}$ exchange and can shed light on how $\mathrm{C}$ is allocated among various pools.

56 However, this requires estimates of difficult-to-measure fluxes (e.g. belowground

57 biomass production), which can introduce substantial uncertainties (Clark et al., 2001)

58 Estimating net $\mathrm{C}$ exchange from changes in major $\mathrm{C}$ stocks offer yet another

59 approach, the benefits of which include its straightforward nature and lack of reliance on

60 difficult-to-measure fluxes. However, belowground C pools are large and notoriously

61 variable, making change detection extremely difficult (Vadeboncoeur et al., 2012). And,

62 on its own, this method doesn't offer insight into mechanisms or subcomponent $\mathrm{C}$ fluxes.

63 Consistency between top-down and bottom-up C quantification approaches can greatly

64 enhance confidence in estimates of an ecosystem's $\mathrm{C}$ balance. Taken together, data from

65 multiple approaches can also provide estimates on a full suite of ecosystem C fluxes to

66 which ecosystem models can be more thoroughly compared.

67 Here we used multiple methodological approaches to compile a comprehensive

68 carbon budget for an aging (100-125 year old) mixed temperate forest in New England

69 (Bartlett Experimental Forest, NH). This included a comparison of net and gross

70 ecosystem C fluxes using 3 complementary approaches (eddy covariance, biometric

71 estimates of NPP and $\mathrm{R}_{\mathrm{h}}$, and a modified C inventory approach) for 13 years (2004-2016)

72 of data. We included estimates of uncertainty for all three approaches, and highlight how

73 the comparison of several independent methodological approaches provided more

74 confidence in estimates of difficult-to-measure respiratory and belowground fluxes.

75 Finally, drivers of interannual variations of $\mathrm{C}$ fluxes were evaluated by comparing net

76 ecosystem production (NEP), gross primary production (GPP), ecosystem respiration

77 (Re), and wood growth to an array of climatic, phenological, and biological variables. 


\section{2. Methods}

\section{2.1. Site description}

80 Bartlett Experimental Forest (BEF) $\left(44^{\circ} 06^{\prime} \mathrm{N}, 71^{\circ} 3^{\prime} \mathrm{W}\right)$ is located within the White

81 Mountain National Forest in north-central New Hampshire, USA (Figure 1). The climate

82 is humid continental with cool summers (mean July temperature, $19^{\circ} \mathrm{C}$ ) and cold winters

83 (mean January temperature, $-9^{\circ} \mathrm{C}$ ). Mean annual temperature is $6^{\circ} \mathrm{C}$ and mean annual

84 precipitation is $1270 \mathrm{~mm}$ (for additional site information, see

85 http://www.fs.fed.us/ne/durham/4155/bartlett.htm). The forest within the eddy

86 covariance tower footprint was cutover circa 1900 and some areas were damaged by the

871938 hurricane. In the past decade there has also been small-scale forest management

88 just outside the tower footprint, but mean stand age is roughly 100-125 years. Average

89 canopy height is approximately $20-22 \mathrm{~m}$ within the tower footprint and is composed of a

90 diverse assemblage of species including Acer rubrum (29\%), Fagus grandifolia (25\%),

91 Tsuga canadensis (14\%), Betula alleghaniensis (9\%), Betula papyrifera (6\%), Fraxinus

92 americana (5\%), Acer saccharum (5\%), and Populus grandidentata (4\%), with minor

93 amounts of other coniferous species. Soils are generally acidic Spodosols and Inceptisols

94 derived from granitic till, and poor in both Ca and P (Vadeboncoeur et al., 2014). Foliar

$95 \mathrm{~N}$ and ecosystem $\mathrm{N}$ cycling rates are both low relative to other mixed hardwood sites in

96 the region (Ollinger et al., 2002).

97 In 2003, BEF was adopted as a NASA North American Carbon Program (NACP)

98 Tier-2 field research and validation site. During this time a $26.5 \mathrm{~m}$ tower was installed in

99 a low-elevation (290 m) mixed hardwood stand for the purpose of making eddy 
100 covariance measurements of the forest-atmosphere exchange of carbon dioxide, water,

101 and sensible heat. Continuous flux and meteorological measurements began in January,

1022004 and are ongoing (data are available online from AmeriFlux,

103 http://www.public.ornl.gov/ameriflux/). In 2004, 12 FIA-style plots (Hollinger, 2008)

104 were established across a $1 \mathrm{~km}$ by $1 \mathrm{~km}$ area centered on the flux tower for the purpose of

105 making complimentary biometric measurements of carbon pools and fluxes. BEF is also

106 a NEON relocatable site (construction began in the summer of 2013) and the new flux

107 tower is located within 100 meters of the existing flux tower.

\section{2.2. Eddy covariance estimates of $\mathrm{C}$ flux and uncertainty}

109 The eddy covariance system provides direct measurements of the net ecosystem

110 exchange rate of $\mathrm{CO}_{2}$ between the forest canopy and the atmosphere (NEE). Eddy

111 covariance estimates of NEE, after accounting for a change in sign, are equivalent to net

112 ecosystem production $\left(\mathrm{NEP}_{\mathrm{EC}}\right.$ ) assuming that sources and sinks of inorganic $\mathrm{C}$ are

113 negligible (Chapin III et al., 2006).

114 Forest-atmosphere $\mathrm{CO}_{2}$ flux (NEE) was measured at a height of $25 \mathrm{~m}$ with an

115 eddy covariance system consisting of a model SAT-211/3K 3- axis sonic anemometer

116 (Applied Technologies, Longmont, Colo.) and ducted to a model LI-6262 $\mathrm{CO}_{2} / \mathrm{H}_{2} \mathrm{O}$

117 infrared gas analyzer (Li-Cor, Lincoln, Neb.), through $2500 \mathrm{~cm}$ of $0.476 \mathrm{~cm} \mathrm{ID}$

118 polyethylene tubing at $75 \mathrm{cc} \mathrm{s}^{-1}$ with data recorded at $5 \mathrm{~Hz}$ and fluxes (covariances)

119 calculated every 30 minutes. In 2014 the LI-6262 was replaced with a model LI-7200

120 analyzer. Average (30 minute) meteorological variables (e.g. air and soil temperatures,

121 incoming solar radiation, etc.) measured at the tower were recorded concurrently. The

122 instrument configuration, calibration protocol, $\mathrm{QA} / \mathrm{QC}$, and data processing procedures 
123 were identical to those used at the Howland AmeriFlux site in central Maine, USA, and

124 have been documented in detail elsewhere (Hollinger et al., 2004). Site visits by the

125 AmeriFlux Tech Team took place in the summers 2006 and 2016, to confirm overall

126 quality of the flux and meteorological measurements.

127 Half-hourly NEE data were filtered to remove time periods with low atmospheric

128 turbulence where advective losses were likely significant similar to Barr et al. (2013).

129 Following this approach a median ustar threshold of $0.50 \pm 0.10$ was detected and used

130 across all seasons and years. Gaps in NEE were filled using the (Barr et al., 2004)

131 Fluxnet-Canada method (FCM) with slight modifications, including: mild exclusion of

132 NEE outliers; use of a weighted mean of soil and air temperature as the independent

133 variable for estimating Re; and delineation of nighttime periods from global shortwave

134 radiation of less than $5 \mathrm{~W} \mathrm{~m}^{2}$. Random uncertainties in NEE were estimated following

135 (Richardson and Hollinger, 2007). NEE was partitioned into gross primary production

$136\left(\mathrm{GPP}_{\mathrm{EC}}\right)$ and total ecosystem respiration $\left(\mathrm{Re}_{\mathrm{EC}}\right)$ using the FCM method. Further details

137 of the gap-filling an partitioning methods used are presented in Barr et al. (2013).

\section{2.3. Biometric estimates of carbon fluxes with uncertainty}

139 In addition to eddy covariance, we used measurements of individual ecosystem

140 components to make biometric estimates of gross and net carbon fluxes. For biometric

141 estimates of $\mathrm{NEP},\left(\mathrm{NEP}_{\mathrm{B}}\right)$, we subtracted heterotrophic respiration $\left(\mathrm{R}_{\mathrm{h}}\right)$, including

142 respiration from dead woody biomass $\left(\mathrm{R}_{\mathrm{DW}}\right)$, and the heterotrophic portion of soil

143 respiration $\left(\mathrm{R}_{\mathrm{SH}}\right)$, from total net primary production (NPP), including NPP from foliage,

144 aboveground woody tissues, understory production, fine and coarse roots, and

145 mycorrhizae (Table 1). We also calculated biometric estimates of gross primary 
146 production $\left(\mathrm{GPP}_{\mathrm{B}}\right)$ and ecosystem respiration $\left(\mathrm{Re}_{\mathrm{B}}\right)$. $\mathrm{GPP}_{\mathrm{B}}$ was calculated by summing

147 all sources of NPP, with all sources of autotrophic respiration, including autotrophic

148 respiration from foliage, aboveground wood, and the autotrophic portion of soil

149 respiration (Table 1). Biometric estimates of $\mathrm{Re}_{\mathrm{B}}$ were calculated by summing all

150 sources of heterotrophic and autotrophic respiration including total soil respiration,

151 respiration from coarse woody debris and standing dead wood, as well as from foliar and

152 woody tissues.

\section{2.3.1. Aboveground production}

154 Beginning in 2004 estimates of aboveground carbon pools and fluxes were made on 12

155 plots within a $1 \mathrm{~km}$ by $1 \mathrm{~km}$ area centered on the flux tower with a similar layout, but

156 larger size, to that described in Hollinger (2008). Each of the 12 plots contains four $10 \mathrm{~m}$

157 radius subplots for a total of 48 subplots within the $1 \mathrm{~km}^{2}$ footprint of the flux tower.

158 Each subplot contains 3 soil respiration collars, 2 litterfall traps, and 1 branchfall

159 collection tarp, resulting in 154 soil respiration collars, 96 litterfall traps, and 48

160 branchfall collection tarps within the $1 \mathrm{~km}^{2}$ footprint around the flux tower. We followed

161 established methods for estimating woody biomass and production (Clark et al., 2001;

162 Curtis, 2008), litterfall and branchfall (Bernier et al., 2008), and biomass of coarse woody

163 debris (Valentine et al., 2008).

164 In each of the 48 subplots within the $1 \mathrm{~km}^{2}$ footprint of the flux tower the

165 location, diameter at breast height (dbh), and species of all trees greater than $12.7 \mathrm{~cm}$

166 were recorded annually from 2004-2016. For small trees (2.54 to $12.7 \mathrm{~cm} \mathrm{dbh),} \mathrm{all} \mathrm{trees}$

167 were measured within a $2 \mathrm{~m}$ radius microplot within each subplot, with microplot center

1684 meters (at an azimuth of $90^{\circ}$ ) from subplot center. Dbh measurements on all trees were 
169 made each year after leaf fall in late October/early November by the same three person

170 team using paint markings to improve the consistency of repeat measurements.

171 To calculate the NPP of live woody tissues (both large and small trees), estimates

172 of live woody biomass of the previous year were subtracted from current year estimates,

173 while holding the dbh of any trees that died throughout the study period constant at the

174 last live measurement as recommended in Clark et al. (2001). Above and belowground

175 woody NPP and associated uncertainty were then calculated using a Monte Carlo

176 simulation approach similar to that described by Yanai et al. (2010). This approach

177 estimates the statistical distribution of the output of a calculation through multiple

178 iterations in which the input data are chosen randomly based on their underlying

179 distributions. Specifically for each iteration the measured diameter of each tree was

180 allowed to vary randomly with a normal distribution using standard deviation (s.d.) of 0.1

$181 \mathrm{~cm}$. The percent carbon $(\% \mathrm{C})$ of woody material was varied randomly for both

182 hardwood species (mean of $48 \%$ and s.d. of 1\%) and for coniferous species (mean of

$18350 \%$ and s.d. of $1 \%$ ). Because many allometric equations lack estimates of error, we

184 simulated uncertainty due to allometric modeling by randomly selecting between 3

185 different sets of allometric models. Two local species specific allometric models

186 (Whittaker et al., 1974; Young et al., 1980), and one set of generalized (taxonomically

187 grouped) allometric models (Chojnacky et al., 2014) were chosen randomly for each

188 iteration. For each iteration, \% $\mathrm{C}$ and choice of allometric model were held constant for

189 all years. The mean and $95 \%$ confidence interval of 1000 iterations were used to derive

190 NPP (difference between current and previous year woody biomass), and associated

191 uncertainty measurements for each subplot for each year. Uncertainties from the Monte 
192 Carlo simulations were propagated with spatial (plot to plot) and temporal variability

193 using classical error propagation techniques (see Section 2.6.).

194 Annual branchfall collections were used to calculate a mean estimate of the

195 contribution of branchfall to woody carbon flux, while annual foliar and fruit/flower

196 collections were used to calculate a mean estimate of carbon flux to foliar/fruit/flower

197 production. Branchfall ( $<5 \mathrm{~cm}$ diameter) was collected once per year in October, using

198 one $3.34 \mathrm{~m}^{2}$ branchfall tarp on each subplot for a total of 48 branchfall tarps. Annual

199 foliar and fruit/flower production were estimated by collection of aboveground litterfall

200 using 2 litterfall traps $\left(0.24 \mathrm{~m}^{2}\right)$ randomly placed in each subplot. Litter was collected 2-

2015 times each fall and once the following spring. To convert branchfall and litterfall into

202 C fluxes, annual biomass collections were multiplied by the mean \%C (49\%).

203 Uncertainty due to \%C, spatial variability, and temporal variability were summed using

204 standard error propagation techniques (using a 2\% standard error for \%C) and reported as

$20595 \%$ confidence intervals.

206 The contribution of understory production to total NPP was estimated using

207 allometric models and annual seedling surveys on 2 meter diameter microplots in each of

208 the 48 subplots, following methods described in (Chojnacky and Milton, 2008).

209 Uncertainty due to spatial and temporal variation as well as uncertainties in \% $\mathrm{C}$ were

210 propagated using standard techniques.

\section{$211 \quad$ 2.3.2. Belowground production}

212 Production of fine roots ( $<2 \mathrm{~mm}$ diameter) was estimated using ingrowth cores. Within

213 the tower footprint, 90 individual year-long (late October 2013 - late October 2014) cores

214 were installed to $30 \mathrm{~cm}$ depth. Total root mass per area found in the ingrowth cores was 
215 assumed to represent annual fine root production. Estimates were not corrected for the

216 tendency of cores to overestimate root biomass or to account for root growth below 30

217 cm depth. Omitting these two biases likely has a small effect on estimates of root

218 production; Park et al. (2007) found that in stands at Bartlett Experimental Forest cores

219 tended to overestimate by $27 \%$ (compared to soil pits) while sampling to only $30 \mathrm{~cm} \mathrm{led}$

220 to a $28 \%$ underestimate of root biomass. Uncertainty due to spatial variation and \%C

$221(49 \% \pm 2 \%)$, were propagated using standard error propagation techniques.

222 Estimates of ectomycorrhizal (ECM) fungal production were made using a stable

223 isotope approach described in (Hobbie and Hobbie, 2008; Ouimette et al., 2013). Briefly,

224 ECM fungi discriminate against ${ }^{15} \mathrm{~N}$ during the creation of nitrogen $(\mathrm{N})$ transfer

225 compounds for plant hosts. The fraction of nitrogen transferred to ECM hosts (Tr) can be

226 calculated (eq. 1), using the fractionation factor during mycorrhizal transfer of $N(\Delta f)$,

227 and the ${ }^{15} \mathrm{~N}:{ }^{14} \mathrm{~N}$ ratios (expressed as $\left.\delta^{15} \mathrm{~N}\right)$ in plant $\left(\delta^{15} \mathrm{~N}_{\text {Plant }}\right)$ and soil available $\mathrm{N}$

$228\left(\delta^{15} \mathrm{~N}_{\text {Avail }}\right)$.

229

$230 \operatorname{Tr}=1+\left(\delta^{15} \mathrm{~N}_{\text {Plant }}-\delta^{15} \mathrm{~N}_{\text {Avail }}\right) / \Delta \mathrm{f}$

232 The amount of $\mathrm{C}$ allocated to ECM fungal biomass can then be calculated

233 stoichiometrically (eq. 2) using the fraction of $\mathrm{N}$ transferred to plant host (Tr), plant host

$234 \mathrm{~N}$ demand, and the $\mathrm{C}: \mathrm{N}$ ratio of fungi as:

235

$236 \mathrm{NPP}_{\text {fungi }}=(1 / \mathrm{Tr}-1) \times \mathrm{N}_{\text {demand }} \times \mathrm{C} / \mathrm{N}_{\text {fungi }} \times \mathrm{f}_{\mathrm{ECM}}$ 
238 where $\mathrm{N}_{\text {demand }}$ is annual plant $\mathrm{N}$ demand, $\mathrm{C} / \mathrm{N}_{\text {fungi }}$ is the $\mathrm{C} / \mathrm{N}$ ratio of $\mathrm{ECM}$ fungi, and $\mathrm{f}_{\mathrm{ECM}}$

239 is the biomass fraction of ECM trees within the stand. Here we used the $\delta^{15} \mathrm{~N}$ of co-

240 located (by depth) root and soil samples to calculate $\operatorname{Tr}$, net annual changes in foliar,

241 wood, and fine root $\mathrm{N}$ stocks to calculate plant $\mathrm{N}$ demand.

242 As an alternative approach to assess our estimates of mycorrhizal production we

243 compared biometric estimates of NEP to estimates of NEP from eddy covariance and C

244 inventory approaches. Specifically, production of mycorrhizal fungi was initially

245 included as a component of $\mathrm{NEP}_{\mathrm{B}}\left(\mathrm{NEP}_{\mathrm{B}}\right.$ was calculated as total NPP minus the

246 heterotrophic portion of ecosystem respiration - Table 1). We additionally calculated

$247 \mathrm{NEP}_{\mathrm{B}}$ omitting our measured mycorrhizal fungal $\mathrm{C}$ flux. To do this we ran Monte Carlo

248 simulations (10,000 iterations) to calculate $\mathrm{NEP}_{\mathrm{B}}$, allowing estimates of each component

249 of NPP and Rh to vary with their measured/estiamted distributions (similar to Yanai et

250 al., 2010). Estimates of $\mathrm{NEP}_{\mathrm{B}}$ that both included and omitted our estimate of mycorrhizal

251 NPP were compared to NEP estimates from eddy covariance and C inventory

252 approaches.

253 Additionally, we estimated total belowground carbon allocation (TBCA) using the

254 mass balance approach described in Raich and Nadelhoffer (1989) and Davidson et al.

255 (2002). Specifically, TBCA was estimated as the difference between total soil respiration

256 and fine litterfall. This approach assumes that changes in the stocks of soil organic

257 matter, roots, and litter are in near steady state or small relative to soil respiration and 258 litterfall.

\section{2.3.3. Soil respiration}


260 Soil respiration was measured using infra-red gas analyzers (IRGA) in conjunction with

261 both static chambers and autochambers. The static chambers consisted of a 10 inch PVC

262 collar permanently inserted $\sim 5 \mathrm{~cm}$ into the soil. Three collars per subplot (144 chambers

263 across the $1 \mathrm{~km}^{2}$ tower footprint) were measured roughly every 3 weeks during the snow-

264 free portion of each year using a LICOR $820 \mathrm{CO}_{2}$ gas analyzer during 2004-2007 (>3400

265 measurements). Simultaneous soil moisture and temperature measurements were made at

$2665 \mathrm{~cm}$ soil depth. Chamber volumes were measured every year but were approximately

2675.5 liters. After scrubbing the chamber to $\sim 30 \mathrm{ppm}$ below ambient $\mathrm{CO}_{2}$ concentrations,

268 concentrations were measured every 2 seconds over a 60 second period. The flux was

269 calculated as follows: flux (umoles $\left.\mathrm{CO}_{2} \mathrm{~m}^{-2} \mathrm{sec}^{-1}\right)=\mathrm{PV} / \mathrm{RTA} *\left(\mathrm{dxCO}_{2} / \mathrm{dt}\right)$, where $\mathrm{P}$ is

270 chamber pressure in bar, $\mathrm{V}$ is chamber volume in $\mathrm{m}^{3}, \mathrm{~T}$ is chamber air temperature in

271 Kelvin, A is chamber area in $\mathrm{m}^{2}, \mathrm{R}$ is the ideal gas law constant or $0.0000834472 \mathrm{~m}^{3}$ bar

$272 \mathrm{~K}^{-1} \cdot \mathrm{mole}^{-1}$, and $(\mathrm{dxCO} / \mathrm{dt})$ is the rate of change of the mole fraction $\mathrm{CO}_{2}$ concentration in 273 the chamber $\left(\right.$ umoles $\left.\sec ^{-1}\right)$.

274 During 2007-2008 five autochambers were operated on a single plot continuously

275 during the snow-free periods of the year (>5600 measurements) following methods

276 described in (Phillips et al., 2010).

277 To derive annual soil $\mathrm{CO}_{2}$ flux estimates for both static and autochambers,

278 measured $\mathrm{CO}_{2}$ flux rates from the chambers were fit using a Gauss-Newton optimization

279 method in JMP 13.0 statistical software (SAS 2016), to a suite of respiration models

280 (Richardson et al., 2006) including $\mathrm{Q}_{10}$ temperature, temperature and time varying $\mathrm{Q}_{10}$,

281 soil water content modulated $\mathrm{Q}_{10}$, Arrhenius, and logistic response functions. For most

282 models, fit parameters did not vary significantly between years for either static or 
283 autochambers (results not shown), thus measurements from all years were pooled to

284 derive modeled parameters for each chamber type.

285 Model best fits (using data from 2004-2008) were applied to continuous (every 30

$286 \mathrm{~min}$ ) temperature and moisture measurements made at the base of the eddy covariance

287 flux tower ( $5 \mathrm{~cm}$ depth) to estimate annual soil $\mathrm{CO}_{2}$ flux rates for each chamber type

288 during all years (2004-2016). Lower and upper 95\% confidence intervals were estimated

289 for each model and chamber type. Since annual $\mathrm{CO}_{2}$ flux rates and model goodness of fit

290 varied minimally among model types, results from a logistic fit are reported to minimize

291 gap-filling artifacts between chamber-based soil respiration and eddy covariance tower-

292 based ecosystem respiration estimates (also modeled logistically).

293 Soil $\mathrm{CO}_{2}$ flux during winter months was estimated using the logistic fit (above),

294 derived from measurements during the snow-free season. Because winter respiration

295 fluxes can be similar in magnitude to NEP, a more direct estimate of wintertime

296 respiration was also made during the winter of 2011-2012 using the soda lime technique

297 described in Grogan (1998) and Keith and Wong (2006). Briefly, roughly $800 \mathrm{~g}$ of oven-

298 dried, soda lime were left from November 17, 2011 to March 21, 2012 (125 days), in an

299 enclosed chamber ( surface area $=0.06783 \mathrm{~m}^{2}$ ). All post-collection soda lime weights

300 were blank-corrected using the mean of 6 field blanks prior to flux calculation. Because

301 estimates of winter respiration using the soda lime technique (data not shown) were

302 similar to those estimated using a logistic fit from chamber measurements, soil $\mathrm{CO}_{2}$ flux

303 during winter months was estimated using the logistic temperature response model

304 described above. 
To scale up to the forest stand, chamber-based soil $\mathrm{CO}_{2}$ flux measurements were

306 corrected for the area occupied by rocks and tree root crowns (roughly 13\%) similar to

307 Bae et al. (2015). Uncertainty was estimated by propagating uncertainty due to soil

308 rockiness, model fit, as well as spatial and temporal variability.

\section{2.3.4. Partitioning Rs into autotrophic and heterotrophic components}

310 No attempt was made to directly measure the contribution of autotrophic $\left(\mathrm{R}_{\mathrm{SA}}\right)$ or

311 heterotrophic $\left(\mathrm{R}_{\mathrm{SH}}\right)$ respiration to total soil respiration $\left(\mathrm{R}_{\mathrm{S}}\right)$. Instead we used several

312 different approaches to partition Rs. First, the Global Database of Soil Respiration

313 Version 3 (Bond-Lamberty and Thomson, 2014) was used to derive a relationship

314 between $\mathrm{R}_{\mathrm{SH}}$ and $\mathrm{R}_{\mathrm{S}}$. We used data from non-experimentally manipulated, temperate,

315 deciduous, forest ecosystems with quality check flags of Q0, Q01, Q02, and Q03 ( $\mathrm{n}=$

316 114) to derive the following relationship between annual $\mathrm{R}_{\mathrm{SH}}$ and $\mathrm{R}_{\mathrm{S}} \mathrm{R}_{\mathrm{SH}}=1.925$

$317( \pm 34.392)+\mathrm{R}_{\mathrm{S}} * 0.534( \pm 0.045)$. This relationship was used with measured estimates of

318 mean annual $\mathrm{R}_{\mathrm{S}}$ to derive annual estimates of $\mathrm{R}_{\mathrm{SH}}$ (and $\mathrm{R}_{\mathrm{SA}}$ by difference). Monte Carlo

319 simulations using the uncertainty in annual $\mathrm{R}_{\mathrm{S}}$ and in the relationship between $\mathrm{R}_{\mathrm{S}}$ and $\mathrm{R}_{\mathrm{SH}}$

320 were used to estimate uncertainty in $\mathrm{R}_{\mathrm{SH}}$ and $\mathrm{R}_{\mathrm{A}}$ and reported as $95 \%$ confidence

321 intervals as described above. As an additional approach to help assess the uncertainty in

322 estimates of $\mathrm{R}_{\mathrm{SH}}$, we estimated $\mathrm{R}_{\mathrm{SH}}$ independently by summing all detritus inputs

323 (branchfall, foliar litterfall and root and mycorrhizal production) following (Bond-

324 Lamberty et al., 2004). This independent approach was compared to estimates of $\mathrm{R}_{\mathrm{SH}}$

325 using the portioning method described above. 


\subsubsection{Respiration from woody biomass}

327 To estimate annual respiratory losses from dead woody material, estimates of dead

328 woody $\mathrm{C}$ stocks were multiplied by the mean decay rate for hardwood species from

329 Russell et al. (2014) (hardwood species comprised 97\% of the standing dead woody

330 biomass pool). Dead woody biomass was assumed to have 49\% C (Thomas and Martin,

331 2012) with a standard error of $2 \%$. Uncertainty due to initial estimates of dead woody

332 biomass, \%C, and decay rates from Russell et al. (2014) were propagated using standard

333 error propagation techniques and reported as $95 \%$ confidence intervals.

334 No direct measurements of respiration from live woody biomass were made.

335 Instead, we used two approaches to estimate losses of $\mathrm{CO}_{2}$ from live woody biomass.

336 First, to derive a "biometric" estimate that was independent of eddy covariance

337 measurements, live woody respiration was assumed to be equal to 0.118 of biometric

338 GPP, the median ratio of woody respiration to GPP of mature and old growth forests (>

33950 years old; $n=16$ ) reported in the database of (Litton et al., 2007). Uncertainty was

340 reported as 0.75 of the mean annual flux.

341 Additionally, we derived estimates of aboveground respiration (including foliage

342 and live and dead woody biomass) as the annual difference between eddy covariance

343 estimates of ecosystem respiration and soil respiration from chamber measurements.

\section{2.3.6. Foliar respiration}

345 Dark respiration for live foliage was estimated using species-specific leaf-level

346 measurements of dark respiration and scaled to the stand and annual scales using

347 estimates of stand leaf area index (LAI) and a temperature sensitive $\mathrm{Q}_{10}$ response

348 function. Specifically, gas exchange measurements of dark respiration were conducted 
349 during August of 2014 and July/August of 2016 on cloud-free days between $1000-1500$

350 EST using a portable gas exchange system (LICOR-6400xt, LICOR, Lincoln, NE, USA),

351 equipped with a standard $2 \times 3 \mathrm{~cm}$ leaf cuvette and a LICOR-6400-02B LED light

352 source. During measurements $\left[\mathrm{CO}_{2}\right]$ was maintained at a value of $400 \mathrm{ppm}$, relative

353 humidity at $50 \%$, and temperature held constant at a temperature of $24.5^{\circ} \mathrm{C}$ (reference

354 temperature). Species-specific estimates of foliar dark respiration ( $\mathrm{n}=75$ across all

355 species) were then weighted by the fractional contribution of each species to stand LAI to

356 derive a stand-level dark respiration rate at the reference temperature $\left(\mathrm{Rd}_{\mathrm{ref}}\right)$.

357 A Q10 response function (eq. 3) was used to estimate dark respiration rates at

358 temperatures other than the reference temperature using $\mathrm{Rd}_{\text {ref }}$ and half hourly

359 measurements of air temperature (periods when PAR $<5$ umoles $\mathrm{m}^{-2} \mathrm{sec}^{-1}$ ), where for eq.

3603 , Tair and Tref, were the measured air temperature and reference air temperature

$361\left(24.5^{\circ} \mathrm{C}\right)$, respectively.

362

363 Foliar dark respiration rate $=\mathrm{Rd}_{\mathrm{ref}} \times \mathrm{Q} 10^{(\text {Tair }- \text { Tref })}$

364

365 Because the Q10 temperature response function of foliar dark respiration is known to

366 vary over short timescales with changes in ambient temperature, Q10 was allowed to vary

367 with ambient temperature following (Tjoelker et al., 2001; $\mathrm{Q}_{10}=3.22-0.046 *$ air

368 temperature). Annual stand-level foliar dark respiration rates were then made by

369 multiplying temperature adjusted dark respiration rates by estimates of stand LAI

370 summing half hourly estimates. 
372 uncertainty in estimates LAI and the temperature response function reported in (Tjoelker

373 et al., 2001) were quantified using Monte Carlo simulations as described above where

374 estimates of each parameter were allow vary with their measured distributions.

\section{2.4. Changes in carbon stocks $(\Delta \mathbf{C})$}

377 To complement eddy covariance and biometric estimates of NEP, we estimated the mean

378 annual change in total ecosystem carbon stocks $(\Delta \mathrm{C})$ using a modified carbon inventory

379 approach. Inventory approaches rely on knowing the carbon stock of various ecosystem

380 pools at two points in time. In closed-canopy forest stands, the pools of primary

381 importance are live and dead woody biomass, as well as soil carbon. Here we focus on

382 changes in woody carbon stocks and assume that changes in soil carbon stocks were

383 minimal as was found from measurements at mature stands in nearby Hubbard Brook

384 Experimental Forest (Yanai et al., 2013). Changes in soil carbon stocks would be very

385 difficult to detect over a 13 year study period (Vadeboncoeur et al., 2012). Instead, in

386 these mature (100-125 year old) stands we assumed that there was little to no net change

387 in annual soil C stocks; however, we included an uncertainty of $\pm 40 \mathrm{~g} \mathrm{C} \mathrm{m}^{-2} \mathrm{yr}^{-1}$ (Post

388 and Kwon, 2000).

389 To estimate changes in woody carbon stocks, we used a modified inventory

390 approach. First, in 2004, we made initial measurements of standing live and dead woody

391 biomass using the allometric approach described above (Section 2.3.1), except that

392 standing dead woody biomass was adjusted using species- and decay-class specific

393 density reduction factors from Harmon et al. (2011), and structural loss adjustment 
394 factors from Domke et al. (2011). In 2004 we also made estimates of dead woody

395 biomass in coarse woody debris (CWD) using field surveys. For all downed woody

396 material $>7.6 \mathrm{~cm}$, estimates of CWD decay class and volume were estimated using 3

397 methods: line intersect sampling (LIS), modified transect relascope sampling (MTRS),

398 and fixed plot sampling, see Pesonen et al. (2009) and Valentine et al. (2008) for details

399 of each method type. For the present study, two 100 meter transects (LIS), one 1 meter

400 transect (MTRS), or four $1 \mathrm{~m}^{2}$ subplots per each of the 12 FIA style plots were sampled.

401 CWD volume was then multiplied by species- and decay class- specific density values

402 from Harmon et al. (2008) to estimate CWD biomass. Total dead woody biomass in

4032004 was estimated as the sum of CWD and standing dead pools.

404 Because we had only a single measurement of standing dead biomass and CWD

405 in 2004, we estimated changes in dead woody biomass using annual inputs to the dead

406 woody pool (from known live tree death and measured branchfall), while accounting for

407 loss of carbon through decay from standing and downed dead wood using a decay rate of

$408 \quad 0.0467$ (the weighted average of the rates reported in Russell et al. (2014) for hardwoods

409 and conifers based on the proportion of standing dead wood in our plots). To derive the

410 mean annual change in total ecosystem carbon stocks $(\Delta C)$ we assumed the

411 predominantly angiosperm woody biomass was comprised of $49 \% \mathrm{C}$ with a standard

412 error of $2 \%$ (Thomas and Martin, 2012). Uncertainty due to initial estimates of dead

413 woody biomass, \%C, and decay rates from Russell et al. (2014), and the assumption of no

414 changes in soil C stocks were propagated using standard error propagation techniques and 415 reported as $95 \%$ confidence intervals. 


\subsection{Potential drivers of interannual variability}

417 To investigate the potential drivers of interannual variation in woody NPP, NEE, GPP,

418 and Re, we used a suite of meteorological and phenological parameters measured at the

419 flux tower including incoming total, direct, and diffuse photosynthetically active

420 radiation (PAR), air and soil temperature, soil thaw day, precipitation, relative humidity,

421 vapor pressure deficit, soil moisture content, the length, start and end dates of periods of

422 gross and net carbon uptake, as well as the length of the vernal window - defined here as

423 the number of days between soil thaw and the onset of gross carbon uptake (where mean

424 daily $\mathrm{GPP}_{\mathrm{EC}}$ averaged over a 7 day period, exceeded 4 umoles $\mathrm{CO}_{2} \mathrm{~m}^{-2} \mathrm{sec}^{-1}$ ). We also

425 calculated a drought index by counting the number of growing season days where the

426 volumetric water content (VWC) was less than $17.5 \%$; a value that represented $50 \%$ of

427 the growing season mean during 2004-2016. In addition to these meteorological and

428 phenological parameters we collected data on biochemical and biological parameters

429 including annual concentrations of foliar nitrogen (estimated following Smith et al.

430 (2008)) and masting years from Potter et al. (2015). Annual estimates of growing season

431 canopy level Amax and dark respiration $\left(\mathrm{R}_{\mathrm{d}}\right)$ from the eddy flux data were estimated

432 using a light response curve (eq. 4). For this analysis, all high-quality (ustar-filtered,

433 non-gapfilled) measurements of half hourly NEP during June-August were used with

434 measured PAR to estimate model parameters (e.g. Amax, Rd).

$$
N E P=\frac{a * \mathrm{PAR}}{\left(\left(1-\frac{P A R}{2000}\right)+\frac{\mathrm{a} * P A R}{A \max }\right)}-R d
$$

436 where PAR was the measured incoming photosynthetically active radiation and $a$ was the 437 quantum yield. 
Both current year and 1 year lagged annual and seasonal data from these metrics

439 were compared to measured $\mathrm{C}$ fluxes using stepwise linear multiple regression analysis

440 with AIC (Akaike information criterion) to identify significant relationships.

\section{2.6. Statistical Methods and Uncertainty Propagation}

442 To combine estimates of uncertainty from various sources (e.g. temporal, spatial,

443 analytical, etc.) standard uncertainty propagation techniques were used. Specifically, to

444 add sources of uncertainty the following approach was taken:

$$
S E_{(x+y)}=\sqrt{\left(S E_{x}\right)^{2}+\left(S E_{y}\right)^{2}}
$$

446 Where SE is standard error of component $x, y$, or $(x+y) .95 \%$ confidence intervals were 447 then estimated as $1.96 * \mathrm{SE}$.

\section{3. Results}

\section{3.1. Estimated carbon fluxes using multiple approaches}

\section{3.1.1. Multiyear mean fluxes}

451 Estimates and associated uncertainties of mean ecosystem C fluxes during 2004-2016 are

452 shown in Table 1 and include components of NPP, respiratory fluxes, and estimates of

453 NEP, GPP, and Re. Mean (2004-2016) estimates of NEPEC, NEP , and $\Delta C$ ranged from

$454 \quad 120-133 \mathrm{~g} \mathrm{C} \mathrm{m}^{-2} \mathrm{yr}^{-1}$, indicating surprising consistency in multiyear mean estimates of

455 ecosystem net carbon flux across top-down and bottom-up approaches. All three

456 approaches indicate that this aging 100-125 year old stand is a moderate carbon sink.

457 Eddy covariance and biometric estimates of mean (2004-2016) GPP and Re also differed 
458 by less than $5 \%$ and were statistically indistinguishable. Total belowground carbon

459 allocation (calculated as soil respiration minus fine litterfall) was estimated at $656 \pm 54 \mathrm{~g}$

$460 \mathrm{C} \mathrm{m}^{-2} \mathrm{yr}^{-1}$, within the range reported for stands of similar age within BEF (620-681 g C

$\left.461 \mathrm{~m}^{-2} \mathrm{yr}^{-1}\right)$ (Bae et al., 2015).

462 The magnitude of uncertainty in NEP, GPP, and Re differed across approaches.

463 For estimates of NEP, eddy covariance $\left(132 \pm 49 \mathrm{~g} \mathrm{C} \mathrm{m}^{-2} \mathrm{yr}^{-1}\right)$ and inventory $(133 \pm 34 \mathrm{~g}$

$\left.464 \mathrm{C} \mathrm{m}^{-2} \mathrm{yr}^{-1}\right)$ approaches had much lower uncertainty than biometric estimates of NEP (120

$\left.465 \pm 156 \mathrm{~g} \mathrm{C} \mathrm{m}^{-2} \mathrm{yr}^{-1}\right)$. Uncertainty in eddy covariance estimates originate both from the

466 measurements themselves as well as filtering and gapfilling procedures. Estimates of the

467 uncertainty due to potential biases in the selection of a ustar filter were not included and

468 would increase the reported uncertainty (Figure 2). Uncertainty in biometric estimates of

469 NEP are largely driven by uncertainties in fine root and mycorrhizal NPP as well as the

470 heterotrophic portion of soil respiration (17\%, 36\%, and $42 \%$ of total error respectively).

471 Because estimates of the production of mycorrhizal fungi are lacking from many

472 forest $\mathrm{C}$ budget efforts, we also used Monte Carlo simulations to calculate $\mathrm{NEP}_{\mathrm{B}}$

473 excluding our mycorrhizal C flux estimates, using only mean fluxes and uncertainty from

474 the other components of $\mathrm{NEP}_{\mathrm{B}}$. Excluding our estimates of mycorrhizal production

475 resulted in $\mathrm{NEP}_{\mathrm{B}}$ near zero $\left(-3 \pm 123 \mathrm{~g} \mathrm{C} \mathrm{m}^{-2} \mathrm{yr}^{-1}\right)$, and an inconsistency between $\mathrm{NEP}_{\mathrm{B}}$

476 and both NEPEC and $\Delta \mathrm{C}$.

\section{$477 \quad 3.1 .2$ Components of NPP}

478 Mean annual NPP was estimated at $615 \pm 118 \mathrm{~g} \mathrm{C} \mathrm{m}^{-2} \mathrm{yr}^{-1}$. Growth of woody biomass

479 including aboveground components of large and small trees, and replacement of 
480 branchfall comprised approximately $33 \%$ of total NPP $\left(238 \pm 30 \mathrm{~g} \mathrm{C} \mathrm{m}^{-2} \mathrm{yr}^{-1}\right)$. Annual

481 production of foliage, fruits, flowers, and seedlings was estimated at $143 \pm 15 \mathrm{~g} \mathrm{C} \mathrm{m}^{-2} \mathrm{yr}^{-}$

$482{ }^{1}$ or $23 \%$ of total NPP. This value may be an underestimate due to removal of seeds from

483 litter baskets by small mammals. Estimates of fine root production and production of

484 mycorrhizae were $110 \pm 64$ and $124 \pm 93 \mathrm{~g} \mathrm{C} \mathrm{m}^{-2} \mathrm{yr}^{-1}$, respectively, and, along with

485 coarse woody roots, resulted in a belowground production estimate that was $44 \%$ of total

486 NPP. Uncertainties in estimated belowground C fluxes to mycorrhizae are unknown, but

487 are likely to be large. If we set this value at $75 \%$ of our measured estimate, then

488 uncertainties in belowground fluxes (including fine root production) accounted for $94 \%$

489 of the uncertainly in total NPP.

490 3.1.3. Respiratory Fluxes

491 Estimates of autotrophic and heterotrophic components of soil $\mathrm{CO}_{2}$ flux, as well as

492 respiration from woody biomass and foliage are shown in Table 1. Soil respiration

493 represented the largest component of ecosystem respiration at $810 \pm 48 \mathrm{~g} \mathrm{C} \mathrm{m}^{-2} \mathrm{yr}^{-1}$.

494 Estimates of soil respiration from manual chambers and autochambers were within 5\% of

495 one another and annual estimates were relatively insensitive to the type of model used to

496 scale instantaneous measurements to annual fluxes (data not shown). Modelled winter

497 fluxes from manual and autochambers were similar to estimates over the same time

498 period using a soda lime technique (data not shown). Annual soil respiration estimates

499 are also within the range estimated at similar stands elsewhere within the Bartlett

500 Experimental Forest (790-864 $\mathrm{g} \mathrm{C} \mathrm{m}^{-2} \mathrm{yr}^{-1}$; Bae et al., 2015).

501 The heterotrophic portion of soil respiration (using the partitioning approach

502 described above) was estimated at $434 \pm 101 \mathrm{~g} \mathrm{C} \mathrm{m}^{-2} \mathrm{yr}^{-1}$, and was the largest 
503 heterotrophic component of ecosystem respiration. In comparison, independent estimates

504 of RsH from summing inputs of detritus were $388 \mathrm{~g} \mathrm{C} \mathrm{m}^{-2} \mathrm{yr}^{-1}$. This value is within the

505 uncertainty but lower than our estimates of $\mathrm{R}_{\mathrm{SH}}$ using the partitioning approach. In the

506 ecosystem is roughly in steady state with regards to soil inputs and outputs, then

507 estimates of $\mathrm{R}_{\mathrm{SH}}$ made by summing detrital inputs are likely underestimates because they

508 exclude inputs from incorporation of CWD and root exudates. Heterotrophic respiration

509 from aboveground dead woody biomass was estimated at $61 \pm 12 \mathrm{~g} \mathrm{C} \mathrm{m}^{-2} \mathrm{yr}^{-1}$.

510 The autotrophic portion of soil respiration was the largest component of

511 autotrophic ecosystem respiration (55\%) at $376 \pm 101 \mathrm{~g} \mathrm{C} \mathrm{m}^{-2} \mathrm{yr}^{-1}$. Autotrophic

512 respiration from foliage and live woody material together make up $45 \%$ of total

513 autotrophic respiration, estimated at $149 \pm 20$ and $153 \pm 114 \mathrm{~g} \mathrm{C} \mathrm{m}^{-2} \mathrm{yr}^{-1}$, respectively.

514 Measurements of the components of ecosystem respiration include soil respiration

515 as well as aboveground foliar and woody respiration. We had measurements for total soil

516 respiration and foliar respiration but lacked direct measurements of respiration from

517 aboveground woody material. To assess the consistency of our estimates of aboveground

518 woody respiration with estimates of other measured carbon fluxes in this system, we

519 compared mean daily estimates of $\operatorname{Re}_{\mathrm{EC}}$ to soil respiration (Rs), to estimate respiration

520 from aboveground components $\mathrm{R}_{\mathrm{abv}}$. The difference between mean annual $\mathrm{Re}_{\mathrm{EC}}$ and $\mathrm{Rs}$

521 was $343 \mathrm{~g} \mathrm{C} \mathrm{m}^{-2} \mathrm{yr}^{-1}$, or $\sim 30 \%$ of $\operatorname{Re}_{\mathrm{EC}}$ (Figure 3a). In comparison, the sum of our

522 estimates of aboveground live foliar and woody autotrophic, as well as dead woody

523 heterotrophic respiration from biometric estimates totaled $363 \mathrm{~g} \mathrm{C} \mathrm{m}^{-2} \mathrm{yr}^{-1}$, roughly $31 \%$

524 of Re $e_{\mathrm{EC}}$. 


\section{3.2. Interannual variation and climate drivers}

526 Considerable interannual variation in several meteorological and phenological variables

527 occurred over the 13 year period (2004-2016) used to calculate mean C fluxes. For

528 example, mean annual air temperature varied by nearly $2^{\circ} \mathrm{C}$, mean spring (Julian days $76-$

529 135) and early summer (Julian days 136-215) air temperatures by more than $3^{\circ} \mathrm{C}$, and

530 mean winter air temperature by more than $6^{\circ} \mathrm{C}$. Variables related to the start of the

531 growing season also differed significantly over the 13 year period with variations in soil

532 thaw day of more than a month, the onset of gross carbon uptake by more than 2 weeks,

533 and the length of the vernal window by more than 5 weeks. In addition, growing season

534 precipitation ranged from 279 to $680 \mathrm{~mm}$, while the number of growing season days with

535 a mean volumetric water content (VWC) less than $17.5 \%$ ranged from 0 to 42 days per

536 year.

537 Interannual variation in eddy covariance estimates of GPP, Re, and NEP during

538 this 13 -year period varied by $\pm 9 \%, \pm 12 \%$, and $\pm 80 \%$ around their means, respectively.

539 We used stepwise multiple regression and model averaging to identify the phenological

540 and meteorological parameters that were most strongly related to interannual variation in

541 C fluxes (e.g. Hui et al., 2003). Using simple regression approaches, a majority of the

542 interannual variation in $\mathrm{GPP}_{\mathrm{EC}}$ were captured using a two-parameter model $\left(\mathrm{r}^{2}=.83 \mathrm{p}<\right.$

543 0.0001) that included growing season soil temperature (negative correlation) and total

544 incoming PAR during the growing season (positive correlation) - the two parameters that

545 were used to parameterize the gap filling models employed for Re $\mathrm{e}_{\mathrm{EC}}$ and $\mathrm{GPP} \mathrm{PC}_{\mathrm{EC}}$,

546 respectively. Similarly, interannual variation in $\mathrm{Re}_{\mathrm{EC}}$ was most strongly related to

547 fluctuations in mean annual soil temperature (positive correlation). 
Because of the predominance of gap-filled estimates in computing annual sums,

549 we took a second approach to assess potential controls on interannual C flux variability

550 using only high quality, half-hourly NEE data to parameterize a simple Michaelis-Menten

551 light-response model. Interannual variation in modelled parameter estimates of canopy

552 level maximum gross carbon uptake (Amax) and dark respiration $(\mathrm{Rd})$ were regressed

553 against meteorological and phenological variables.

554 The strongest correlation with growing season (June-August) Amax, was the

555 length of the vernal window, defined here as the number of days between soil thaw and

556 the start of the C uptake period $\left(r^{2}=0.74, p<0.00031\right.$; Figure 4b). Taken separately, soil

557 thaw day was also significantly, positively correlated with Amax $\left(r^{2}=0.44, p=0.019\right.$;

558 Figure $4 \mathrm{a})$, while the start of $\mathrm{C}$ uptake was not $(\mathrm{p}=0.12)$. A longer vernal window (and

559 an earlier soil thaw day) was correlated with a lower canopy Amax. Adding additional

560 parameters did not result in an improved model and we did not detect a correlation

561 between Amax and previous year net or gross $\mathrm{C}$ uptake at annual or seasonal time scales.

562 Interannual variation in estimates of canopy-level dark respiration from the light-response

563 model was positively correlated to Amax $\left(r^{2}=0.69, p=0.0009\right)$, and, showed a similar

564 negative correlation with the length of the vernal window $\left(r^{2}=0.47 p=0.0014\right.$

565 Annual wood growth (Figure 5a) was compared to both current-year and previous

566 year meteorological and phenological variables as well as $\mathrm{GPP}_{\mathrm{EC}}$ and $\mathrm{NEP}_{\mathrm{EC}}$, across a

567 range of time periods (seasons). No significant relationship was detected between annual

568 wood production and variations in gross or net carbon uptake from any time period

569 (current-year or lagged). Instead wood growth was best predicted with a two parameter

570 model that included early summer air temperature and the number of growing season 
571 days with soil volumetric water content less than $17.5 \%\left(\mathrm{r}^{2}=0.75, \mathrm{p}<0.002, \mathrm{RMSE}=\right.$

$57216.9 \mathrm{~g} \mathrm{C} \mathrm{m}^{-2} \mathrm{yr}^{-1}$; Figure $5 \mathrm{~b}$ ), with higher wood growth rates occurring in warmer and

573 wetter years.

\section{4. Discussion}

\section{4.1. Comparison of top-down and bottom-up approaches and}

\section{6 uncertainty using mean C fluxes}

577 Any technique for quantifying ecosystem-scale carbon dynamics has both strengths and

578 limitations. Comparing top-down eddy covariance estimates of $\mathrm{C}$ exchange and bottom-

579 up biometric estimates of $\mathrm{C}$ fluxes can serve as a valuable cross-validation tool, and can

580 improve estimates of both an ecosystem's carbon balance as well as its components. At

581 BEF, differences in 13 year mean (2004-2016) estimates of NEP, GPP, and Re between

582 eddy covariance and biometric approaches were all within $10 \%$ of one another, indicating

583 surprising consistency between methods despite large difference in their underlying

584 sources of error. Consistency between eddy covariance and biometric approaches is

585 often seen when comparing multiyear mean estimates. For example, at a secondary

586 successional mixed northern hardwood forest in Michigan, the difference between NEP

587 from eddy covariance and biometric approaches varied by up to $148 \%$ for individual

588 years, but converged to within $1 \%$ of one another using 5 year mean estimates (Gough et

589 al., 2008).

590 The agreement in eddy covariance and biometric $\mathrm{C}$ flux estimates at BEF

591 provided confidence in estimates of difficult-to-measure $\mathrm{C}$ fluxes, and highlighted the

592 advantage of complementary methodological approaches. For example, the flux tower at 
593 BEF is situated within a valley at $250 \mathrm{~m}$ above sea level, and on all sides the surrounding

594 land rises to $>750$ meters above sea level within $3 \mathrm{~km}$ of the flux tower (Figure 1). This

595 topographic relief increases the potential for advective transport of $\mathrm{CO}_{2}$, which could lead

596 to underestimates of $\mathrm{C}$ exchange measured at the top of the eddy covariance flux tower.

597 Advective losses are a well-known challenge when using the eddy covariance technique

598 and have been dealt with in several ways; the most common being the application of a

599 ustar (friction velocity) threshold filter to exclude data when atmospheric turbulence is

600 not developed enough to minimize horizontal advective transport(Aubinet, 2008; Aubinet

601 et al., 2012). Following the ustar filter threshold selection approach of Barr et al. (2013),

602 the high ustar threshold determined at $\operatorname{BEF}\left(0.5 \mathrm{~m} \mathrm{~s}^{-1}\right)$, in addition to other data gaps

603 resulted in exclusion of $>90 \%$ of available nighttime data (Figure 2). Despite this

604 tradeoff in data quantity, using only high quality, ustar filtered data, resulted in good

605 agreement with biometric approaches.

606 The use of biometric data to estimate NEP, GPP, and Re requires estimates of C

607 flux to several ecosystem pools that are extremely difficult to measure. At BEF

608 aboveground fluxes of net primary production are relatively well-constrained, while

609 belowground $\mathrm{C}$ fluxes to fine roots and especially mycorrhizal fungi have higher

610 uncertainty. However, not including estimates of these difficult-to-measure fluxes

611 resulted in an inconsistency between biometric and eddy covariance estimates of gross

612 and net $\mathrm{C}$ fluxes. In lieu of making individual estimates of fine root and mycorrhizal

613 production, a mass balance approach to estimate total belowground carbon allocation

614 (TBCA) described in (Davidson et al., 2002), can be used, although it does not

615 distinguish between fine root and mycorrhizal fungi production. This approach assumes 
616 that soil carbon stocks are at or near steady state and requires only estimates of soil

617 respiration and aboveground fine litterfall. At BEF, TBCA was estimated at $656 \pm 54 \mathrm{~g} \mathrm{C}$

$618 \mathrm{~m}^{-2} \mathrm{yr}^{-1}$, similar to estimates of the sum of coarse and fine root production, mycorrhizal

619 production, and soil autotrophic respiration, $644 \mathrm{~g} \mathrm{C} \mathrm{m}^{-2} \mathrm{yr}^{-1}$.

620 Estimates of aboveground foliar and woody respiration are also difficult to

621 constrain given their biological control and temporal heterogeneity. The difference

622 between estimates of ecosystem respiration and soil respiration is a mass balance

623 approach that can estimate respiration of aboveground ecosystem components (Giasson et

624 al., 2013). At BEF, this approach yielded similar results $\left(343 \mathrm{~g} \mathrm{C} \mathrm{m}^{-2} \mathrm{yr}^{-1}\right)$ to our initial

625 estimates of aboveground respiration $\left(363 \pm 117 \mathrm{~g} \mathrm{C} \mathrm{m}^{-2} \mathrm{yr}^{-1}\right)$. This mass balance

626 approach also yields estimates at a fine temporal resolution and may capture important

627 phenological events (Davidson et al., 2006). At BEF estimates of $R_{a b v}$ using this mass

628 balance approach highlight the phenological influence on aboveground respiration, with

$629 \mathrm{R}_{\mathrm{abv}}$ contributing a relatively large proportion of Re during spring leaf out (and the onset

630 of wood growth) and during autumn leaf senescence (Figure 3b).

631 The consistency of our initial C flux estimates with mass balance approaches that

632 used soil respiration, aboveground litterfall, and $\mathrm{Re}_{\mathrm{EC}}$ to calculate TBCA and $\mathrm{R}_{\mathrm{abv}}$,

633 demonstrate the benefit of including these as routine data streams at eddy covariance

634 network sites. Including soil respiration and litterfall measurements at flux sites provides

635 valuable information on both above and belowground ecosystem $\mathrm{C}$ fluxes allowing for

636 not only cross validation of ecosystem $\mathrm{C}$ fluxes but the ability to more rigorously test

637 ecosystem models (McFarlane et al., 2014; Phillips et al., 2017). 


\subsection{Interannual variation}

\section{$639 \quad$ 4.2.1 GPP, Re, Amax}

640 Interannual variations in GPP, Re, NEP, and parameters describing light response

641 functions are determined by both direct and indirect drivers, and have the potential to

642 provide insight into how ecosystems might respond under future climate. A complication

643 in understanding the drivers of interannual $\mathrm{C}$ variation from eddy covariance is the

644 abundance of gap-filled data. At BEF, on average, $90-95 \%$ of nighttime and nearly $50 \%$

645 of daytime fluxes during the growing season were gap-filled. It is thus not surprising that

646 interannual variation in gap-filled $\mathrm{GPP} \mathrm{EC}_{\mathrm{EC}}$ and $\mathrm{Re}_{\mathrm{EC}}$ were strongly related to temperature

647 and incoming PAR, the two variables used to parameterize the gap-filling models.

648 Although short term (hours to days) changes in temperature and PAR are

649 frequently correlated to short term variations in C fluxes (and hence why they are used in

650 gap-filling models), they may not be directly related to interannual variation in C fluxes.

651 Several studies have shown the importance of variation in the biotic response to abiotic

652 drivers, especially for regulating interannual carbon flux variation (Richardson et al.,

653 2007). Data from BEF support a similar conclusion. For example, using only high-

654 quality, raw (not gap-filled) data, the strong relationship between growing season canopy

655 Amax (and Rd) and the length of the vernal window suggests that indirect mechanisms

656 (biotic responses) are important in regulating canopy $\mathrm{C}$ exchange.

657 Mechanisms through which the length of the vernal window can influence canopy

658 photosynthesis are not well understood. In the northeastern US, a longer vernal window

659 has been correlated to winters with a reduced snowpack (Contosta et al., 2016). Other

660 studies have repeatedly linked reduced snowpack to an increase in soil freeze-thaw events 
661 and increases in the loss of nutrients through both dissolved and gaseous pathways

662 (Matzner and Borken, 2008; Song et al., 2017). For example, at the Hubbard Brook

663 Experimental Forest (40 km west of BEF), both experimental (Campbell et al., 2014;

664 Fitzhugh et al., 2001) and observational studies across a climate gradient (Durán et al.,

665 2016) have shown increased losses of nitrogen and decreased $\mathrm{N}$ availability following

666 winters with reduced snowpack. Whether decreases in soil nutrient availability prior to

667 leaf out results in decreased foliar biomass, lower canopy nitrogen content, or reduced

668 photosynthetic capacity is still unknown. However, leaf area index (LAI) is often limited

669 by soil nutrients and water (Cowling and Field, 2003), and numerous studies have shown

670 significant increases in foliar biomass and LAI following fertilization, e.g. Gower et al.

671 (1992).

672 In addition to reductions in nutrient availability, earlier snowmelt has been shown

673 to intensify forest hydrological cycles and increase springtime runoff (Creed et al., 2015).

674 Late growing season water stress related to earlier snowmelt has also been suggested as

675 the driver of decreases in peak growing season productivity in boreal forests (Buermann

676 et al., 2013) and temperate forests of the western US (Hu et al., 2010). At BEF the length

677 of the vernal window is negatively correlated to soil moisture during the month prior to

678 leaf out $\left(\mathrm{r}^{2}=0.40, \mathrm{p}=0.027\right)$ but not to soil moisture during the late growing season $\left(\mathrm{r}^{2}=\right.$

$6790.17, \mathrm{p}=0.16)$. Although mechanisms relating growing season Amax to the length of the

680 vernal window are not fully known, data from BEF suggest that winter and spring

681 conditions can exert a strong influence over ecosystem $\mathrm{C}$ dynamics during the growing 682 season. 
A few studies in temperate forests have found lagged effects on C fluxes (e.g.

684 Howland Experimental Forest, Maine; (Richardson et al., 2013)). At BEF we did not

685 detect a correlation between prior year meteorological conditions or $\mathrm{C}$ uptake, with

686 current year C fluxes. In other work at BEF, Carbone et al., (2013) found that in stem

687 wood of Acer rubrum trees, the nonstructural carbohydrate pool included both fast

688 (younger) and slow (older) cycling subpools that could support growth and respiration of

689 woody tissues. The lack of a correlation we see between wood growth and prior year

690 climate and C fluxes may in part be the result of the growth habit of foliage of tree

691 species at BEF. At BEF foliage and new shoots of the majority of the dominant species

692 within the flux tower footprint have an indeterminate growth habit, meaning that during

693 and after spring leaf expansion from the winter bud, the shoot apex remains active and

694 continues to initiate additional leaves and shoot internodes if conditions are favorable. Of

695 the dominant species only American beech and sugar maple tend to have determinate

696 type foliar and shoot growth, where the number of leaf buds (number of leaves) is

697 determined at the end of the preceding growing season. Many ecosystem models allocate

$698 \mathrm{C}$ to foliar growth based more on a determinant type growth.

\section{4.2.2. Wood growth}

700 Despite the importance of wood growth for a variety of ecosystem services, we still do

701 not fully understand the mechanisms controlling variability in wood growth and how they

702 may respond under future climate scenarios. Evidence from broad-scale analyses suggest

703 a tradeoff between $\mathrm{C}$ allocation to wood versus fine roots, reflecting a tradeoff between

704 acquiring growth limiting nutrients and/or water and competition for space in the sunlit 
canopy (Dybzinski et al., 2011; Litton et al., 2007). Whether this tradeoff at ecosystem

706 scales occurs interannually within an ecosystem is unknown.

707 Alternatively, wood growth is often viewed as "source" (C supply) versus "sink"

708 (C demand) limited (Körner, 2015). At broad spatial scales wood growth generally

709 correlates to GPP (Litton et al., 2007). This is why wood growth in many terrestrial

710 ecosystem models is primarily source-driven, where wood production is linked to the

711 amount of gross photosynthesis. However, recent work has downplayed the importance

712 of $\mathrm{C}$ source in controlling wood growth and has emphasized the importance of

713 climatically sink-driven metabolic and phenological processes (Delpierre et al., 2016,

714 2015; Guillemot et al., 2015; Körner, 2003). These studies indicate an earlier onset of

715 xylogenesis, faster rates of cell division, and faster rates of cell division under warmer,

716 wetter conditions.

717 Our inability to detect a correlation between wood growth and either GPP or NEP

718 at BEF suggests that interannual variations in wood growth are likely not directly "source

719 driven." Instead, wood growth is more strongly related to early growing season air

720 temperature and growing season soil water stress. At BEF, wood growth was higher

721 during years with warmer air temperatures during the early growing season and in years

722 with ample growing season soil moisture, consistent with metabolic/phenologically

723 "sink" driven mechanisms. Further, at BEF Carbone et al. (2013) showed the importance

724 of stored $\mathrm{C}$ to the growth and metabolism of woody biomass, indicating that $\mathrm{C}$ allocated

725 towards wood growth relies on both recent photosynthate as well as internal reserve C

726 pools derived from both older and recent photosynthates. At broad-scales allocation to

727 wood growth is likely controlled by C source (GPP) as well as tradeoffs involved in 
728 acquiring growth limiting nutrients, while metabolically driven mechanisms may be

729 important in regulating interannual variability within a site.

\section{5. Conclusion}

731 Long-term datasets using multiple approaches to estimate ecosystem carbon fluxes can

732 provide cross validation of difficult-to-measure fluxes as well as potential insight into

733 mechanisms that may be regulating $\mathrm{C}$ fluxes. At BEF, top-down and bottom-up

734 approaches to estimate gross and net $\mathrm{C}$ exchange agreed well at a multiyear scale and

735 provided more confidence in several difficult-to-measure $\mathrm{C}$ fluxes such as aboveground

736 components of ecosystem respiration and belowground allocation to mycorrhizal fungi.

737 The results from BEF also suggest several potential relationships that may be important

738 to understanding forest ecosystem $\mathrm{C}$ fluxes under future climate. These include potential

739 indirect effects of winter and spring climate (vernal window) on growing season

740 photosynthesis, as well as direct metabolic (sink-driven) mechanisms driven by growing

741 season climate. Such mechanisms warrant future study to assess their importance and to

742 allow for their potential inclusion in models aimed at predicting ecosystem $\mathrm{C}$ dynamics

743 under future conditions.

\section{Acknowledgements}

745 Research at the Bartlett Experimental Forest is supported by the USDA Forest Service's

746 Northern Research Station. We acknowledge funding support from the following grants:

747 National Science Foundation awards \#DEB-1114804, \#1638688, and \# 1114804;

748 Northeastern States Research Cooperative \#12DG11242307065; Hubbard Brook Long

749 Term Ecological Research program, NSF 1114804; NH EPSCoR Program NSF Research 
750 Infrastructure Improvement Award \# EPS 1101245; NASA Carbon Cycle Science

751 Awards \#NNX08AG14G and \#NNX14AJ18G; NASA Terrestrial Ecology Award

752 \#NNX11AB88G. TFK was supported by the Director, Office of Science, Office of

753 Biological and Environmental Research of the US Department of Energy under Contract

754 DE-AC02-05CH11231 as part of the RGCM BGC-Climate Feedbacks SFA. We also

755 acknowledge the staff at Bartlett Experimental Forest, in particular Chris Costello, as

756 well as the invaluable assistance of numerous students over the last 13 years. 
Citations

Aubinet, M., 2008. Eddy Covariance Co2 Flux Measurements in Nocturnal Conditions: An Analysis of the Problem. Ecol. Appl. 18, 1368-1378. https://doi.org/10.1890/06-1336.1

Aubinet, M., Feigenwinter, C., Heinesch, B., Laffineur, Q., Papale, D., Reichstein, M., Rinne, J., Gorsel, E.V., 2012. Nighttime Flux Correction, in: Aubinet, M., Vesala, T., Papale, D. (Eds.), Eddy Covariance, Springer Atmospheric Sciences. Springer Netherlands, pp. 133-157. https://doi.org/10.1007/978-94-007-2351-1_5

Bae, K., Fahey, T.J., Yanai, R.D., Fisk, M., 2015. Soil Nitrogen Availability Affects Belowground Carbon Allocation and Soil Respiration in Northern Hardwood Forests of New Hampshire. Ecosystems 1-13. https://doi.org/10.1007/s10021015-9892-7

Barr, A.G., Black, T.A., Hogg, E.H., Kljun, N., Morgenstern, K., Nesic, Z., 2004. Interannual variability in the leaf area index of a boreal aspen-hazelnut forest in relation to net ecosystem production. Agric. For. Meteorol. 126, 237-255. https://doi.org/10.1016/j.agrformet.2004.06.011

Barr, A.G., Richardson, A.D., Hollinger, D.Y., Papale, D., Arain, M.A., Black, T.A., Bohrer, G., Dragoni, D., Fischer, M.L., Gu, L., Law, B.E., Margolis, H.A., McCaughey, J.H., Munger, J.W., Oechel, W., Schaeffer, K., 2013. Use of changepoint detection for friction-velocity threshold evaluation in eddy-covariance studies. Agric. For. Meteorol. 171-172, 31-45. https://doi.org/10.1016/j.agrformet.2012.11.023

Bernier, P., Hanson, P.J., Curtis, P.S., 2008. Measuring Litterfall and Branchfall, in: Hoover, C.M. (Ed.), Field Measurements for Forest Carbon Monitoring. Springer Netherlands, pp. 91-101. https://doi.org/10.1007/978-1-4020-8506-2_7

Bond-Lamberty, B., Thomson, A., 2014. A global database of soil respiration data, Version 3.0. Data Set Available -Line Httpdaacornlgov Oak Ridge Natl. Lab. Distrib. Act. Arch. Cent. Oak Ridge Tenn. USA Httpdxdoiorg103334ORNLDAAC1235.

Bond-Lamberty, B., Wang, C., Gower, S.T., 2004. A global relationship between the heterotrophic and autotrophic components of soil respiration? Glob. Change Biol. 10, 1756-1766. https://doi.org/10.1111/j.1365-2486.2004.00816.x

Buermann, W., Bikash, P.R., Jung, M., Burn, D.H., Reichstein, M., 2013. Earlier springs decrease peak summer productivity in North American boreal forests. Environ. Res. Lett. 8, 024027. https://doi.org/10.1088/1748-9326/8/2/024027

Campbell, J.L., Socci, A.M., Templer, P.H., 2014. Increased nitrogen leaching following soil freezing is due to decreased root uptake in a northern hardwood forest. Glob. Change Biol. 20, 2663-2673. https://doi.org/10.1111/gcb.12532

Carbone, M.S., Czimczik, C.I., Keenan, T.F., Murakami, P.F., Pederson, N., Schaberg, P.G., Xu, X., Richardson, A.D., 2013. Age, allocation and availability of nonstructural carbon in mature red maple trees. New Phytol. 200, 1145-1155. https://doi.org/10.1111/nph.12448

Caspersen, J.P., Pacala, S.W., Jenkins, J.C., Hurtt, G.C., Moorcroft, P.R., Birdsey, R.A., 2000. Contributions of Land-Use History to Carbon Accumulation in U.S. Forests. Science 290, 1148-1151. https://doi.org/10.1126/science.290.5494.1148 
802

803

804

805

806

807

808

809

810

811

812

813

814

815

816

817

818

819

820

821

822

823

824

825

826

827

828

829

830

831

832

833

834

835

836

837

838

839

840

841

842

843

844

845

846

Chapin III, F.S., Woodwell, G.M., Randerson, J.T., Rastetter, E.B., Lovett, G.M., Baldocchi, D.D., Clark, D.A., Harmon, M.E., Schimel, D.S., Valentini, R., Wirth, C., Aber, J.D., Cole, J.J., Goulden, M.L., Harden, J.W., Heimann, M., Howarth, R.W., Matson, P.A., McGuire, A.D., Melillo, J.M., Mooney, H.A., Neff, J.C., Houghton, R.A., Pace, M.L., Ryan, M.G., Running, S.W., Sala, O.E., Schlesinger, W.H., Schulze, E.-D., 2006. Reconciling Carbon-cycle Concepts, Terminology, and Methods. Ecosystems 9, 1041-1050. https://doi.org/10.1007/s10021-0050105-7

Chojnacky, D.C., Heath, L.S., Jenkins, J.C., 2014. Updated generalized biomass equations for North American tree species. Forestry 87, 129-151. https://doi.org/10.1093/forestry/cpt053

Chojnacky, D.C., Milton, M., 2008. Measuring Carbon in Shrubs, in: Hoover, C.M. (Ed.), Field Measurements for Forest Carbon Monitoring. Springer Netherlands, pp. 4572. https://doi.org/10.1007/978-1-4020-8506-2_5

Clark, D.A., Brown, S., Kicklighter, D.W., Chambers, J.Q., Thomlinson, J.R., Ni, J., 2001. Measuring net primary production in forests: concepts and field methods. Ecol. Appl. 11, 356-370. https://doi.org/10.1890/10510761(2001)011[0356:MNPPIF]2.0.CO;2

Contosta, A.R., Adolph, A., Burchsted, D., Burakowski, E., Green, M., Guerra, D., Albert, M., Dibb, J., Martin, M., McDowell, W.H., Routhier, M., Wake, C., Whitaker, R., Wollheim, W., 2016. A longer vernal window: the role of winter coldness and snowpack in driving spring transitions and lags. Glob. Change Biol. n/a-n/a. https://doi.org/10.1111/gcb.13517

Cowling, S.A., Field, C.B., 2003. Environmental control of leaf area production: Implications for vegetation and land-surface modeling. Glob. Biogeochem. Cycles 17, 1007. https://doi.org/10.1029/2002GB001915

Creed, I.F., Hwang, T., Lutz, B., Way, D., 2015. Climate warming causes intensification of the hydrological cycle, resulting in changes to the vernal and autumnal windows in a northern temperate forest. Hydrol. Process. 29, 3519-3534. https://doi.org/10.1002/hyp.10450

Curtis, P.S., 2008. Estimating Aboveground Carbon in Live and Standing Dead Trees, in: Hoover, C.M. (Ed.), Field Measurements for Forest Carbon Monitoring. Springer Netherlands, pp. 39-44. https://doi.org/10.1007/978-1-4020-8506-2_4

Davidson, E.A., Richardson, A.D., Savage, K.E., Hollinger, D.Y., 2006. A distinct seasonal pattern of the ratio of soil respiration to total ecosystem respiration in a spruce-dominated forest. Glob. Change Biol. 12, 230-239. https://doi.org/10.1111/j.1365-2486.2005.01062.x

Davidson, E.A., Savage, K., Bolstad, P., Clark, D.A., Curtis, P.S., Ellsworth, D.S., Hanson, P.J., Law, B.E., Luo, Y., Pregitzer, K.S., Randolph, J.C., Zak, D., 2002. Belowground carbon allocation in forests estimated from litterfall and IRGAbased soil respiration measurements. Agric. For. Meteorol., FLUXNET 2000 Synthesis 113, 39-51. https://doi.org/10.1016/S0168-1923(02)00101-6

Delpierre, N., Berveiller, D., Granda, E., Dufrêne, E., 2016. Wood phenology, not carbon input, controls the interannual variability of wood growth in a temperate oak forest. New Phytol. 210, 459-470. https://doi.org/10.1111/nph.13771 
Delpierre, N., Vitasse, Y., Chuine, I., Guillemot, J., Bazot, S., Rutishauser, T., Rathgeber, C.B.K., 2015. Temperate and boreal forest tree phenology: from organ-scale processes to terrestrial ecosystem models. Ann. For. Sci. 73, 5-25. https://doi.org/10.1007/s13595-015-0477-6

Domke, G.M., Woodall, C.W., Smith, J.E., 2011. Accounting for density reduction and structural loss in standing dead trees: Implications for forest biomass and carbon stock estimates in the United States. Carbon Balance Manag. 6, 14. https://doi.org/10.1186/1750-0680-6-14

Durán, J., Morse, J.L., Groffman, P.M., Campbell, J.L., Christenson, L.M., Driscoll, C.T., Fahey, T.J., Fisk, M.C., Likens, G.E., Melillo, J.M., Mitchell, M.J., Templer, P.H., Vadeboncoeur, M.A., 2016. Climate change decreases nitrogen pools and mineralization rates in northern hardwood forests. Ecosphere 7, n/a-n/a. https://doi.org/10.1002/ecs2.1251

Dybzinski, R., Farrior, C., Wolf, A., Reich, P.B., Pacala, S.W., 2011. Evolutionarily Stable Strategy Carbon Allocation to Foliage, Wood, and Fine Roots in Trees Competing for Light and Nitrogen: An Analytically Tractable, Individual-Based Model and Quantitative Comparisons to Data. Am. Nat. 177, 153-166. https://doi.org/10.1086/657992

Fitzhugh, R.D., Driscoll, C.T., Groffman, P.M., Tierney, G.L., Fahey, T.J., Hardy, J.P., 2001. Effects of soil freezing disturbance on soil solution nitrogen, phosphorus, and carbon chemistry in a northern hardwood ecosystem. Biogeochemistry 56, 215-238. https://doi.org/10.1023/A:1013076609950

Giasson, M.-A., Ellison, A.M., Bowden, R.D., Crill, P.M., Davidson, E.A., Drake, J.E., Frey, S.D., Hadley, J.L., Lavine, M., Melillo, J.M., Munger, J.W., Nadelhoffer, K.J., Nicoll, L., Ollinger, S.V., Savage, K.E., Steudler, P.A., Tang, J., Varner, R.K., Wofsy, S.C., Foster, D.R., Finzi, A.C., 2013. Soil respiration in a northeastern US temperate forest: a 22-year synthesis. Ecosphere 4, 1-28. https://doi.org/10.1890/ES13.00183.1

Goodale, C.L., Apps, M.J., Birdsey, R.A., Field, C.B., Heath, L.S., Houghton, R.A., Jenkins, J.C., Kohlmaier, G.H., Kurz, W., Liu, S., Nabuurs, G.-J., Nilsson, S., Shvidenko, A.Z., 2002. Forest carbon sinks in the northern hemisphere. Ecol. Appl. 12, 891-899. https://doi.org/10.1890/10510761(2002)012[0891:FCSITN]2.0.CO;2

Gough, C.M., Vogel, C.S., Schmid, H.P., Su, H.-B., Curtis, P.S., 2008. Multi-year convergence of biometric and meteorological estimates of forest carbon storage. Agric. For. Meteorol., Chequamegon Ecosystem-Atmosphere Study Special Issue: Ecosystem-Atmosphere Carbon and Water Cycling in the Temperate Northern Forests of the Great Lakes RegionGreat Lakes Region Special Issue 148, 158-170. https://doi.org/10.1016/j.agrformet.2007.08.004

Gower, S.T., Vogt, K.A., Grier, C.C., 1992. Carbon Dynamics of Rocky Mountain Douglas-Fir: Influence of Water and Nutrient Availability. Ecol. Monogr. 62, 4365. https://doi.org/10.2307/2937170

Grogan, P., 1998. Co2 flux measurement using soda lime: correction for water formed during co2 adsorption. Ecology 79, 1467-1468. https://doi.org/10.1890/00129658(1998)079[1467:CFMUSL]2.0.CO;2 
892

893

894

895

896

897

898

899

900

901

902

903

904

905

906

907

908

909

910

911

912

913

914

915

916

917

918

919

920

921

922

923

924

925

926

927

928

929

930

931

932

933

934

935

936

937

Guillemot, J., Martin-StPaul, N.K., Dufrêne, E., François, C., Soudani, K., Ourcival, J.M., Delpierre, N., 2015. The dynamic of the annual carbon allocation to wood in European tree species is consistent with a combined source-sink limitation of growth: implications for modelling. Biogeosciences 12, 2773-2790.

Harmon, M.E., Woodall, C.W., Fasth, B., Sexton, J., 2008. Woody detritus density and density reduction factors for tree species in the United States: a synthesis.

Harmon, M.E., Woodall, C.W., Fasth, B., Sexton, J., Yatkov, M., 2011. Differences between standing and downed dead tree wood density reduction factors: A comparison across decay classes and tree species.

Hobbie, E.A., Hobbie, J.E., 2008. Natural Abundance of 15N in Nitrogen-Limited Forests and Tundra Can Estimate Nitrogen Cycling Through Mycorrhizal Fungi: A Review. Ecosystems 11, 815. https://doi.org/10.1007/s10021-008-9159-7

Hollinger, D.Y., 2008. Defining a Landscape-Scale Monitoring Tier for the North American Carbon Program, in: Hoover, C.M. (Ed.), Field Measurements for Forest Carbon Monitoring. Springer Netherlands, pp. 3-16. https://doi.org/10.1007/978-1-4020-8506-2_1

Hollinger, D.Y., Aber, J., Dail, B., Davidson, E.A., Goltz, S.M., Hughes, H., Leclerc, M.Y., Lee, J.T., Richardson, A.D., Rodrigues, C., Scott, N. a., Achuatavarier, D., Walsh, J., 2004. Spatial and temporal variability in forest-atmosphere CO2 exchange. Glob. Change Biol. 10, 1689-1706. https://doi.org/10.1111/j.13652486.2004.00847.x

Hu, J., Moore, D.J.P., Burns, S.P., Monson, R.K., 2010. Longer growing seasons lead to less carbon sequestration by a subalpine forest. Glob. Change Biol. 16, 771-783. https://doi.org/10.1111/j.1365-2486.2009.01967.x

Hui, D., Luo, Y., Katul, G., 2003. Partitioning inter annual variability in net ecosystem exchange between climatic variability and functional change. Tree Physiol. 23, $433-442$.

Keith, H., Wong, S.C., 2006. Measurement of soil CO2 efflux using soda lime absorption: both quantitative and reliable. Soil Biol. Biochem. 38, 1121-1131. https://doi.org/10.1016/j.soilbio.2005.09.012

Körner, C., 2015. Paradigm shift in plant growth control. Curr. Opin. Plant Biol. 25, 107114. https://doi.org/10.1016/j.pbi.2015.05.003

Körner, C., 2003. Carbon limitation in trees. J. Ecol. 91, 4-17. https://doi.org/10.1046/j.1365-2745.2003.00742.x

Litton, C.M., Raich, J.W., Ryan, M.G., 2007. Carbon allocation in forest ecosystems. Glob. Change Biol. 13, 2089-2109. https://doi.org/10.1111/j.13652486.2007.01420.x

Luyssaert, S., Schulze, E.-D., Börner, A., Knohl, A., Hessenmöller, D., Law, B.E., Ciais, P., Grace, J., 2008. Old-growth forests as global carbon sinks. Nature 455, $213-$ 215. https://doi.org/10.1038/nature07276

Matzner, E., Borken, W., 2008. Do freeze-thaw events enhance C and N losses from soils of different ecosystems? A review. Eur. J. Soil Sci. 59, 274-284. https://doi.org/10.1111/j.1365-2389.2007.00992.x

McFarlane, K., Finzi, A., Nave, L., Tang, J., 2014. Recommendations for belowground carbon data and measurements for the AmeriFlux Network [WWW Document]. ISCN. URL http://iscn.fluxdata.org/community/publication/recommendations-for- 
belowground-carbon-data-and-measurements-for-the-ameriflux-network/ (accessed 4.18.17).

Novick, K., Brantley, S., Miniat, C.F., Walker, J., Vose, J.M., 2014. Inferring the contribution of advection to total ecosystem scalar fluxes over a tall forest in complex terrain. Agric. For. Meteorol. 185, 1-13. https://doi.org/10.1016/j.agrformet.2013.10.010

Odum, E.P., 1969. The Strategy of Ecosystem Development. Science 164, 262-270. https://doi.org/10.1126/science.164.3877.262

Ollinger, S.V., Smith, M.L., Martin, M.E., Hallett, R.A., Goodale, C.L., Aber, J.D., 2002. Regional Variation in Foliar Chemistry and N Cycling among Forests of Diverse History and Composition. Ecology 83, 339-355. https://doi.org/10.2307/2680018 Ouimette, A., Guo, D., Hobbie, E., Gu, J., 2013. Insights into root growth, function, and mycorrhizal abundance from chemical and isotopic data across root orders. Plant Soil 367, 313-326. https://doi.org/10.1007/s11104-012-1464-4

Park, B.B., Yanai, R.D., Vadeboncoeur, M.A., Hamburg, S.P., 2007. Estimating Root Biomass in Rocky Soils using Pits, Cores, and Allometric Equations. Soil Sci. Soc. Am. J. 71, 206-213. https://doi.org/10.2136/sssaj2005.0329

Pesonen, A., Leino, O., Maltamo, M., Kangas, A., 2009. Comparison of field sampling methods for assessing coarse woody debris and use of airborne laser scanning as auxiliary information. For. Ecol. Manag. 257, 1532-1541. https://doi.org/10.1016/j.foreco.2009.01.009

Phillips, C.L., Bond-Lamberty, B., Desai, A.R., Lavoie, M., Risk, D., Tang, J., ToddBrown, K., Vargas, R., 2017. The value of soil respiration measurements for interpreting and modeling terrestrial carbon cycling. Plant Soil 413, 1-25. https://doi.org/10.1007/s11104-016-3084-X

Phillips, S.C., Varner, R.K., Frolking, S., Munger, J.W., Bubier, J.L., Wofsy, S.C., Crill, P.M., 2010. Interannual, seasonal, and diel variation in soil respiration relative to ecosystem respiration at a wetland to upland slope at Harvard Forest. J. Geophys. Res. Biogeosciences 115, G02019. https://doi.org/10.1029/2008JG000858

Post, W.M., Kwon, K.C., 2000. Soil carbon sequestration and land-use change: processes and potential. Glob. Change Biol. 6, 317-327. https://doi.org/10.1046/j.13652486.2000.00308.x

Potter, D., Obbard, M., Howe, E., 2015. Ontario wildlife food survey, 2014. Ont. Minist. Nat. Resour. For. Sci. Res. Branch Peterb. Ont. Sci. Res. Tech. Rep. TR-01.

Raich, J.W., Nadelhoffer, K.J., 1989. Belowground Carbon Allocation in Forest Ecosystems: Global Trends. Ecology 70, 1346-1354. https://doi.org/10.2307/1938194

Richardson, A.D., Braswell, B.H., Hollinger, D.Y., Burman, P., Davidson, E.A., Evans, R.S., Flanagan, L.B., Munger, J.W., Savage, K., Urbanski, S.P., Wofsy, S.C., 2006. Comparing simple respiration models for eddy flux and dynamic chamber data. Agric. For. Meteorol. 141, 219-234. https://doi.org/10.1016/j.agrformet.2006.10.010

Richardson, A.D., Carbone, M.S., Keenan, T.F., Czimczik, C.I., Hollinger, D.Y., Murakami, P., Schaberg, P.G., Xu, X., 2013. Seasonal dynamics and age of stemwood nonstructural carbohydrates in temperate forest trees. New Phytol. 197, 850-861. https://doi.org/10.1111/nph.12042 
984

985

986

987

988

989

990

991

992

993

994

995

996

997

998

999

1000

1001

1002

1003

1004

1005

1006

1007

1008

1009

1010

1011

1012

1013

1014

1015

1016

1017

1018

1019

1020

1021

1022

1023

1024

1025

1026

1027

Richardson, A.D., Hollinger, D.Y., 2007. A method to estimate the additional uncertainty in gap-filled NEE resulting from long gaps in the $\mathrm{CO} 2$ flux record. Agric. For. Meteorol. 147, 199-208. https://doi.org/10.1016/j.agrformet.2007.06.004

Richardson, A.D., Hollinger, D.Y., Aber, J.D., Ollinger, S.V., Braswell, B.H., 2007. Environmental variation is directly responsible for short- but not long-term variation in forest-atmosphere carbon exchange. Glob. Change Biol. 13, 788-803. https://doi.org/10.1111/j.1365-2486.2007.01330.x

Russell, M.B., Woodall, C.W., Fraver, S., D’Amato, A.W., Domke, G.M., Skog, K.E., 2014. Residence Times and Decay Rates of Downed Woody Debris Biomass/Carbon in Eastern US Forests. Ecosystems 17, 765-777. https://doi.org/10.1007/s10021-014-9757-5

Smith, M.-L., Hollinger, D.Y., Ollinger, S., 2008. Estimation of Forest Canopy Nitrogen Concentration, in: Hoover, C.M. (Ed.), Field Measurements for Forest Carbon Monitoring. Springer Netherlands, pp. 197-203. https://doi.org/10.1007/978-14020-8506-2_15

Song, Y., Zou, Y., Wang, G., Yu, X., 2017. Altered soil carbon and nitrogen cycles due to the freeze-thaw effect: A meta-analysis. Soil Biol. Biochem. 109, 35-49. https://doi.org/10.1016/j.soilbio.2017.01.020

Thomas, S.C., Martin, A.R., 2012. Carbon Content of Tree Tissues: A Synthesis. Forests 3, 332-352. https://doi.org/10.3390/f3020332

Tjoelker, M.G., Oleksyn, J., Reich, P.B., 2001. Modelling respiration of vegetation: evidence for a general temperature-dependent Q10. Glob. Change Biol. 7, 223230. https://doi.org/10.1046/j.1365-2486.2001.00397.x

Vadeboncoeur, M.A., Hamburg, S.P., Blum, J.D., Pennino, M.J., Yanai, R.D., Johnson, C.E., 2012. The Quantitative Soil Pit Method for Measuring Belowground Carbon and Nitrogen Stocks. Soil Sci. Soc. Am. J. 76, 2241-2255. https://doi.org/10.2136/sssaj2012.0111

Vadeboncoeur, M.A., Hamburg, S.P., Yanai, R.D., Blum, J.D., 2014. Rates of sustainable forest harvest depend on rotation length and weathering of soil minerals. For. Ecol. Manag. Complete, 194-205. https://doi.org/10.1016/j.foreco.2014.01.012

Valentine, H.T., Gove, J.H., Ducey, M.J., Gregoire, T.G., Williams, M.S., 2008. Estimating the Carbon in Coarse Woody Debris with Perpendicular Distance Sampling, in: Hoover, C.M. (Ed.), Field Measurements for Forest Carbon Monitoring. Springer Netherlands, pp. 73-87. https://doi.org/10.1007/978-14020-8506-2_6

van Gorsel, E., Delpierre, N., Leuning, R., Black, A., Munger, J.W., Wofsy, S., Aubinet, M., Feigenwinter, C., Beringer, J., Bonal, D., Chen, B., Chen, J., Clement, R., Davis, K.J., Desai, A.R., Dragoni, D., Etzold, S., Grünwald, T., Gu, L., Heinesch, B., Hutyra, L.R., Jans, W.W.P., Kutsch, W., Law, B.E., Leclerc, M.Y., Mammarella, I., Montagnani, L., Noormets, A., Rebmann, C., Wharton, S., 2009. Estimating nocturnal ecosystem respiration from the vertical turbulent flux and change in storage of CO2. Agric. For. Meteorol., Special Section on Water and Carbon Dynamics in Selected Ecosystems in China 149, 1919-1930. https://doi.org/10.1016/j.agrformet.2009.06.020 
1028

1029

1030

1031

1032

1033

1034

1035

1036

1037

1038

1039

1040

1041

1042

1043

1044
Vickers, D., Irvine, J., Martin, J.G., Law, B.E., 2012. Nocturnal subcanopy flow regimes and missing carbon dioxide. Agric. For. Meteorol. 152, 101-108. https://doi.org/10.1016/j.agrformet.2011.09.004

Whittaker, R.H., Bormann, F.H., Likens, G.E., Siccama, T.G., 1974. The Hubbard Brook Ecosystem Study: Forest Biomass and Production. Ecol. Monogr. 44, 233-254. https://doi.org/10.2307/1942313

Yanai, R.D., Battles, J.J., Richardson, A.D., Blodgett, C.A., Wood, D.M., Rastetter, E.B., 2010. Estimating Uncertainty in Ecosystem Budget Calculations. Ecosystems 13, 239-248. https://doi.org/10.1007/s10021-010-9315-8

Yanai, R.D., Vadeboncoeur, M.A., Hamburg, S.P., Arthur, M.A., Fuss, C.B., Groffman, P.M., Siccama, T.G., Driscoll, C.T., 2013. From Missing Source to Missing Sink: Long-Term Changes in the Nitrogen Budget of a Northern Hardwood Forest. Environ. Sci. Technol. 47, 11440-11448. https://doi.org/10.1021/es4025723

Young, H.E., Ribe, J.H., Wainwright, K., 1980. Weight tables for tree and shrub species in Maine. Maine Life Sci. Agric. Exp. Stn. Misc. Rep. USA. 

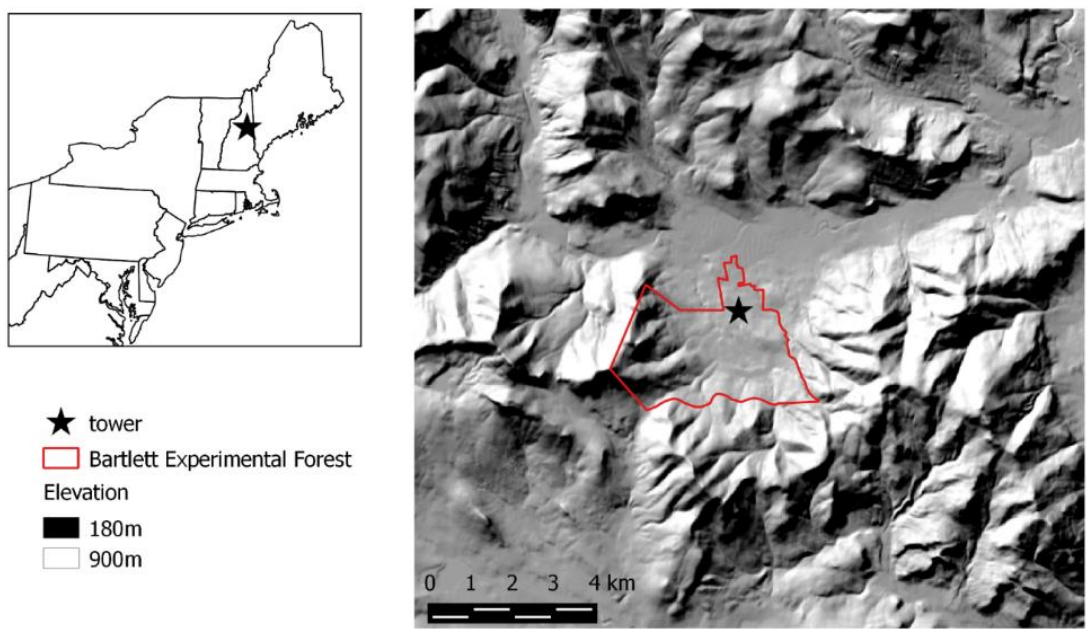

Figure 1: A) Location of Bartlett Experimental Forest (BEF); B) Representation of topography surrounding BEF.

1048

1049

1050

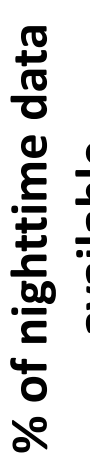

Figure 2: Plot of the percent of available nighttime data during the growing season (circles) and

1053 mean annual ecosystem respiration (triangles) with changes in ustar, highlighting the tradeoff 1054 between data quantity and data quality at BEF.

1055

1056

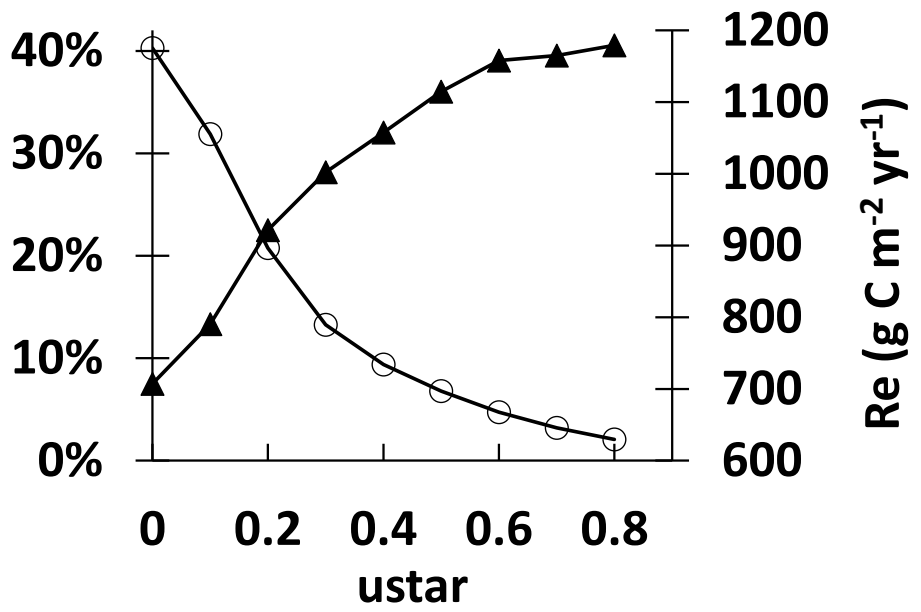



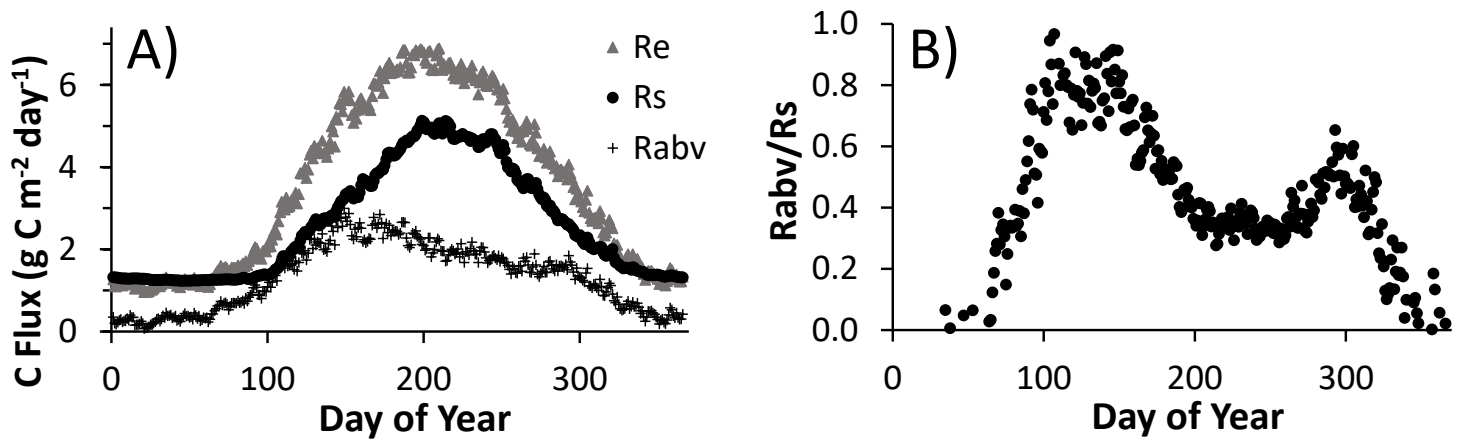

1058 Figure 3: A) Mean daily $\mathrm{CO}_{2}$ flux by day of year for ecosystem respiration $\left(\mathrm{Re}_{\mathrm{EC}}\right)$, soil respiration

1059 (Rs), and respiration from aboveground components of the ecosystem $\left(\mathbf{R}_{\mathrm{abv}}\right)$; B) Ratio of $\mathbf{R}_{\mathrm{abv}}$ to $\mathbf{R s}$

1060 by day of year.

1061

1062

1063
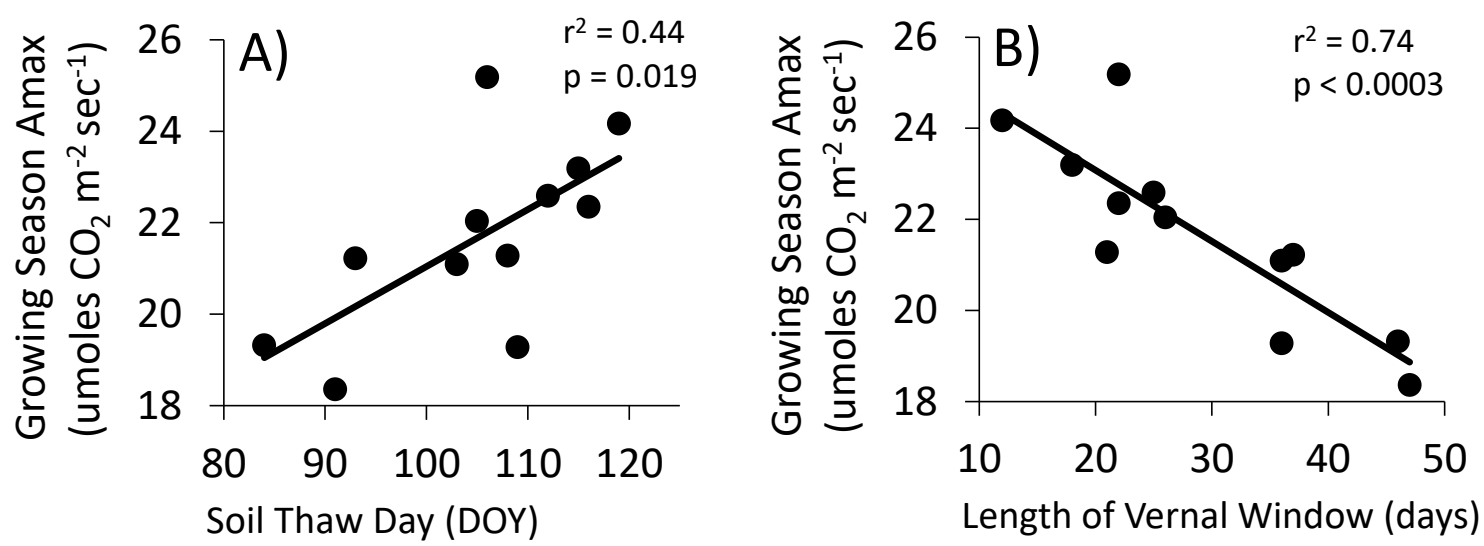

1065 Figure 4: Relationship between growing season canopy level Amax and (A) soil thaw day, and (B) the

1066 length of the vernal window during 2004-2016. The vernal window is defined as the number of days

1067 between soil thaw and the start of canopy gross carbon uptake. 

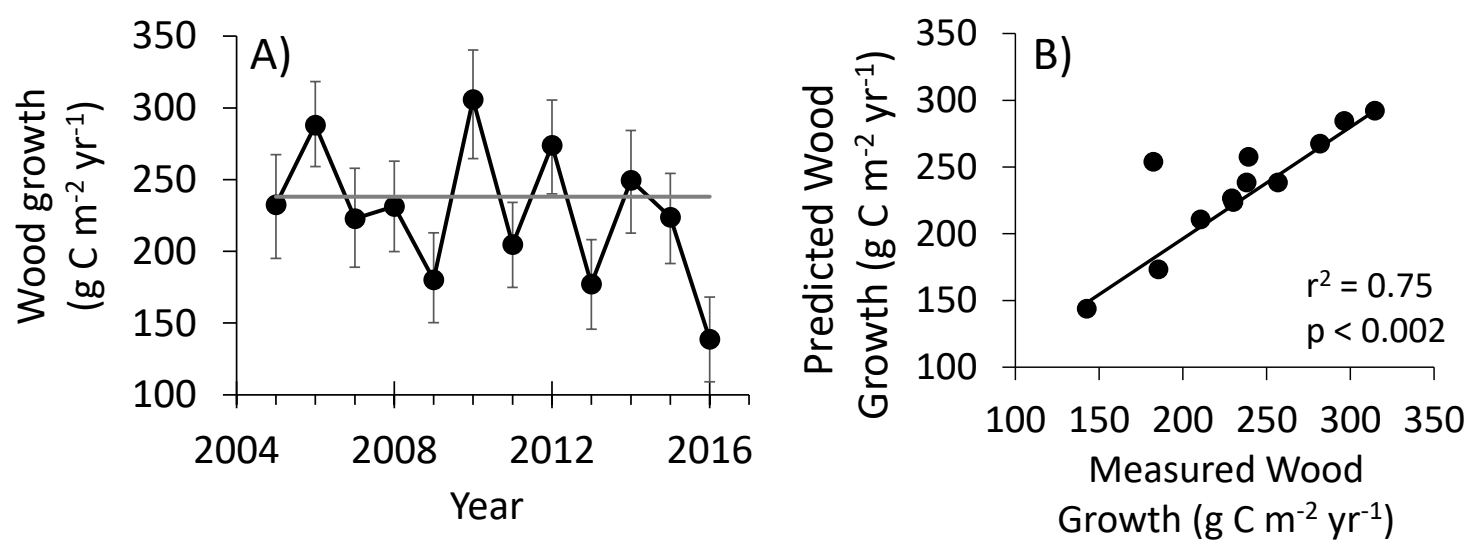

1070 Figure 5: A) Annual wood growth during 2004-2016 including both aboveground biomass and coarse 1071 roots. B) Predicted vs. measured wood growth. Predicted wood growth was estimated from a 2

1072 parameter linear regression model using early summer air temperature (Julian days 136-215) and a

1073 drought index (the number of growing season days with VWC $<17.5 \%$; $50 \%$ of the growing season

1074 mean VWC). The outlier in B) is $\mathbf{2 0 1 3}$ where measured wood growth was much lower than

1075 predicted.

1076 
Components of Net Primary Production Flux $\left(\mathrm{g} \mathrm{C} \mathrm{m}^{-2} \mathrm{yr}^{-1}\right)$ Method

(a) Aboveground Wood

1) Large trees $(>12.7 \mathrm{~cm} \mathrm{dbh})$

2) Small trees $(<12.7 \mathrm{~cm} \mathrm{dbh})$

$204 \pm 29 \quad(1+2+3)$

\begin{tabular}{l|l}
\hline 3$)$ branchfall & $31 \pm 21$
\end{tabular}

(b) Foliage, fruit, flower

(c) Understory/herbivory

$123 \pm 11$

(d) Woody roots $20 \pm 10$

(e) Fine roots $34 \pm 7$

(f) Mycorrhizae $110 \pm 64$

$124 \pm 93$

(h) Total NPP

$615 \pm 118$

Allometry; annual DBH Allometry; annual DBH Annual branchfall tarps Annual litterfall collection Allometery on microplots Allometry; annual DBH Root ingrowth cores Stable isotope approach $(a+b+c+d+e+f)$

\section{Respiratory Fluxes}

(i) Total Soil Respiration $(R$

(j) CWD respiration

(k) Standing dead respiration

(l) Woody autotrophic respiration

(m) Foliar respiration

(n) Heterotrophic Soil Respiration $\left(\mathrm{R}_{\mathrm{SH}}\right)$

(o) Autotrophic Soil respiration $\left(\mathrm{R}_{\mathrm{SA}}\right)$

$810 \pm 48 \quad$ Manual and auto-chambers

$5 \pm 5 \quad$ CWD mass; mass loss rates

$56 \pm 15 \quad$ Allometry; mass loss rates

\begin{tabular}{l|l}
$153 \pm 114$ & $0.118 * \mathrm{GPP}_{\mathrm{B}}$; see methods
\end{tabular}

$149 \pm 20 \quad$ leaf level measurements

\begin{tabular}{l|l}
$434 \pm 101$ & $1.92+0.534 *(\mathrm{i}) ;$ see methods
\end{tabular}

\section{Ecosystem Fluxes}

\begin{tabular}{|l|c|l|}
\hline $\mathrm{NEP}_{\mathrm{EC}}$ & $132 \pm 49$ & eddy covariance flux tower $(-\mathrm{NEE})$ \\
\hline $\mathrm{NEP}_{\mathrm{B}}$ & $120 \pm 156$ & $\mathrm{NPP}-\mathrm{R}_{\mathrm{h} ;}(\mathrm{h}-\mathrm{j}-\mathrm{k}-\mathrm{n})$ \\
\hline$\Delta \mathrm{C}$ & $133 \pm 34$ & modified inventory approach \\
\hline $\operatorname{Re}_{\mathrm{EC}}$ & $1153 \pm 69$ & eddy covariance flux tower \\
\hline $\operatorname{Re}_{\mathrm{B}}$ & $1172 \pm 127$ & $(\mathrm{i}+\mathrm{j}+\mathrm{k}+\mathrm{l}+\mathrm{m})$ \\
\hline
\end{tabular}

\begin{tabular}{|l|c|l|}
\hline $\mathrm{GPP}_{\mathrm{EC}}$ & $1285 \pm 62$ & eddy covariance flux tower \\
\hline $\mathrm{GPP}_{\mathrm{B}}$ & $1292 \pm 194$ & $(\mathrm{~h}+1+\mathrm{m}+\mathrm{o})$ \\
\hline
\end{tabular}

\begin{tabular}{l|l}
$656 \pm 54$ & $(\mathrm{i}-\mathrm{b}-3)$
\end{tabular}

